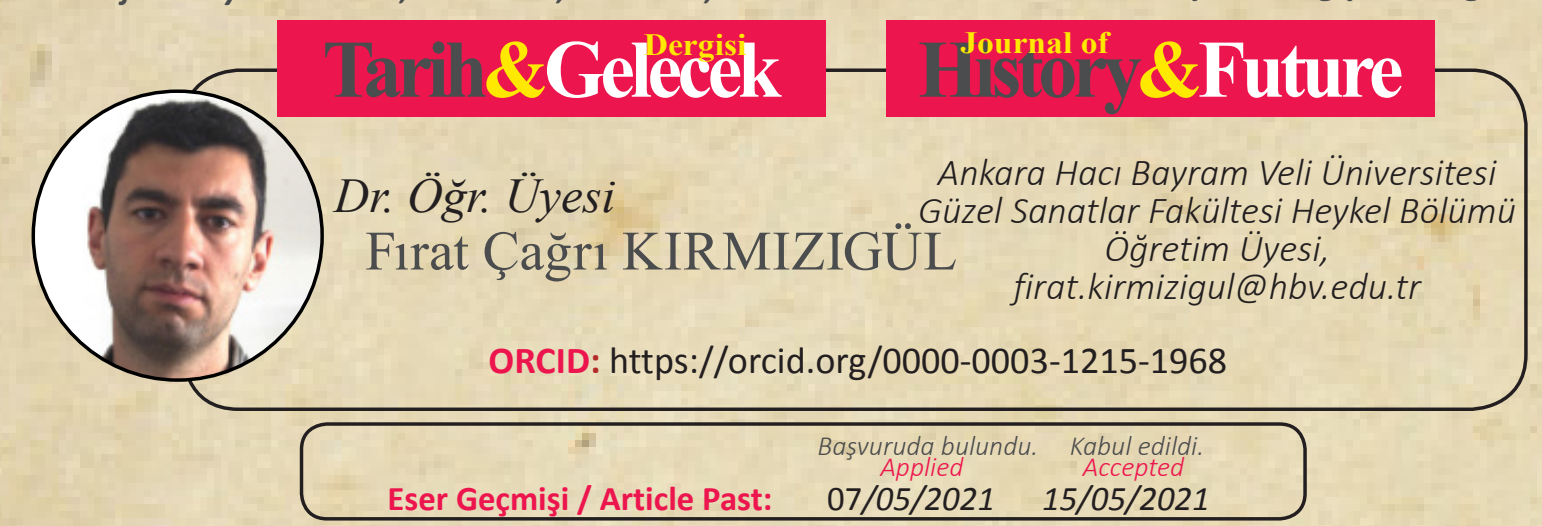

Araştırma Makalesi

DOI: http://dx.doi.org/10.21551/jhf.934277

Research Paper

Indexed by

ERIHPDUNALS

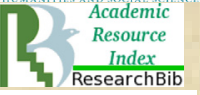

Q $\mathbf{I} \mid \mathbf{S A M}$

Orjinal Makale / Orginal Paper

\title{
Sosyal Bir Kimlik Arketipi Olarak KKTC - Kapalı Maraş Bölgesinin Mekânsal Yalnızlığı Üzerine Kurgusal Denemeler
}

\author{
Fictional Trials on the Spatial Solitude of the Northern Cyprus \\ Turkish Republic (NCTR) Closed Maraş (Varosha) Region as a \\ Social Identity Archetype
}

Öz

Mekân kavramı, oluşumunda farklı içeriklere sahip olan ve kimliksel eylemlerle biçimlenen evrendeki sınırsız yaşam aurasına sahip alanlardır. Bu alanlar insan ile girdiği karşılıklı medeniyet temelli etkileşim ile ortak bir analojik bilinç oluşturan ve aynı zamanda bu bilince dayalı çoklu bellek mekanizmaları yaratan kimlik katmanlarından oluşur. Mekanlar oluşum sürecinde dinamik kodlamalara dayalı arketiplerin dokümantasyonu temeline göre içerisinde coğrafi, mimari, demografik, stratejik, kültürel ve siyasi sacayakları bulunan kavram uzamları ile betimlenen en büyük anlam dizeleridir. Bu çalışmada sosyal doku arketipine uygun olarak geçmişten günümüze her daim önemli ve bir o kadar da jeostratejik noktada Doğu Akdeniz, Kuzey Afrika, Ortadoğu gibi bölgelerin kilit bir konumunda bulunan Kıbrıs adasının zengin medeniyete dayalı sosyo-kültürel ve siyasi gelişmeler 1şı̆̆ındaki belleğe dayalı tipolojik yapısı irdelenmiştir. Yapılan bu araştırmada genelde Kıbrıs aidiyeti üzerinden, özelde ise Kuzey Kıbrıs Türk Cumhuriyeti’nin Gazimağusa kentinde bulunan Kapalı Maraş bölgesinin geçmişten günümüze olan serüvenindeki insansız ve yalnız yapısı halihazırda bölge içerisinde bulunan doğa ve mekân bazlı elemanlar üzerinden simgesel bir tarzda ele alınmış, yarım asıra yakındır bu sessiz ve ıssız şekilde duran bölgenin yapısal biçemi güncel ve disiplinlerarası sanat yaklaşımları ile analitik ve ontolojik belleğe dayalı bilinç parametreleri üzerinden ayrıntılı olarak detaylandırılmıştır.

Anahtar Kelimeler: Kıbrıs, Kapalı Maraş, Sanat, Mekân, Bellek

\section{Abstract}

The idea of space is a realm that is formed by various contents and has an aura of infinite existence in the universe shaped by identity acts. These areas are made up of layers of identity that, in conjunction with the shared civilization-related interactions it has with humans, establish a collective analogical 
consciousness and, at the same time, multiple memory structures based on that consciousness. Spaces are the longest strings of meaning represented with design spaces, which have geographical, architectural, demographic, strategic, cultural, and political trivets and are focused on the documentation of archetypes based on complex coding in the creation phase. In this study, the memory and typological structure of the island of Cyprus, which has always been significant from the past to the present in compliance with the archetype of social fabric and has a key geostrategic role in regions such as the Eastern Mediterranean, North Africa, and the Middle East, are examined in the light of socio-cultural and political developments based on rich Cypriot archives. In this research, the uninhabited and lonely structure of the closed Maraş (Varosha) region, which is located in Gazimağusa (Famagusta) city of the Turkish Republic of Northern Cyprus in general and in particular, in its adventure from the past to the present, has been handled in a symbolic style through the nature and space-based elements in the region, The structural style of the region, which has remained silent and uninhabited for nearly a half century, is elaborated in detail through contemporary and interdisciplinary art approaches and the parameters of consciousness based on analytical and ontological memory.

Keywords: Cyprus, Closed Maraş (Varosha), Art, Space, Memory

\section{Giriş}

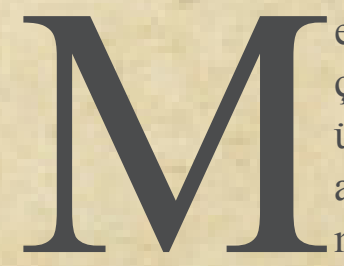

ekanlar bağlı bulunduğu konum ve kültürlere göre biçimlenen bir aidiyet çizgisi içerisinde her daim güncelliğini koruyan topografik yapılar üzerinde coğrafi ve sosyolojik kimlik katmanlarına göre şekillenen, ayrıca analojik yönleri de bulunan sınırsız yaşam alanlarıdır. Bu bakımdan mekân kavramı, üzerindeki medeniyetlere bağlı olarak gelişme gösteren ve mündemiç bellek arketiplerinden oluşan ortak bilinç parametreleridir. Mekanlar coğrafi ve jeopolitik yer dizgesine bağlı içerisinde çeşitli katmanlara sahip bir aidiyet içerisinde organik ve organik olmayan yapı taşlarına sahip yer biçemleri olan, ayrıca demografik ve toplumsal katmanlarla daha da büyüyerek yeni "alan" tarifnameleri yaratan sonsuz bir analitiğe de sahiptir. Bu bakımdan Cevizci'nin de belirttiği üzere mekân kavramı "var olan her şeyin içinde yer aldığı, eni, boyu ve derinliği olan kap ya da hazne olarak tanımlanırken aynı zamanda... içine bir şeyler yerleştirilinceye kadar boş olan bir kap ya da hazne olarak var olur. Bazı düşünürler bir kap ya da hazne olarak mekânın sonsuz olduğunu, ya da dış sınırları bulunmadığını söylerken, diğer bazıları mekânın sonlu olduğunu savunmuşlardır"l

Mekân kavramı yukarıda belirttiğimiz betimlemeler ve çıkarımlara bağlı ifadelerin yanında ayrıca üzerinde belirli biçemlerde karşımıza çıkan çok detaylı sonsuz bir bellek morfolojisinin de en büyük belirteçleri arasındadır. Bu belirteçler sosyal, kültürel, demografik, topografik, tipolojik ve beşerî ilişkiler ağı ile birbirlerine bağlı dokümantasyonlarla çoklu parametrelere bağlı kavramların 'yer' tarifnamesi ile oluşan soyut ve somut doğa yanında yapısal katmanlar üzerindeki müdahaleleridir. Bu bir bakıma 'yukarıda belirtilen 'kap olarak mekân' görüşüyle, şeyleri ön plana çıkartan 'bağıntısal mekân' görüşünün bir sentezini yaparak, mekân ve şeylerin birbirlerini tamamladığını öne süren 'çok yönlü mekân' görüşüdür”’2

1 Ahmet Cevizci, Felsefe Sözlüğü, Say Yayınları, İstanbul 2012, s.296.

2 Ahmet Cevizci, Paradigma Felsefe Sözlüğ̈̈, Paradigma Yayınc1lık, İstanbul 2013, s. 1080. 
Mekân kavramı özellikle 18. Yüzyıla kadar doğa temelli yaşam mottosuna sahip alanlar üzerinde organik bir doğa uyumu ile bütünleşik hal almış fakat bu durum özellikle moderniteden sonra o güne kadar görülmemiş çok farklı yapılarla kentleşme üzerinde organik olmayan yeni paradigmaların oluşmasını sağlamış ve daha sonra hayatın tüm alanlarındaki parametrelerdeki aktif alan ve sayısal kodlu değişkenlerin oluşumuna sebebiyet vermiştir. Yaşanan bu yeni paradigma değişimiyle birlikte moderniteye bağlı olarak siyasal, sosyal ve dinsel olaylara bağlı değişiklik gösteren kimlik aidiyetleri ile birlikte ortaya çıkan yeni dünyada hammadde ve pazar arayışlarına bağlı gelişen yeni tip sanayi düzeni beraberinde devletleri yeniden konumlandırma sürecine sokarak dünya savaşlarının bu sebepler temelinde başlamasına neden olmuş ve alanların paylaşılması noktasında mekân fenomeni üzerinde "yer" kavramını üst bir dokümantasyon parametresine taşıyarak yerin mekan ile olan dinamiğinde ortak bir anagram biçemini oluşturan meşruiyete sahip olmuştur.

Dinamik bir öge olarak sürekli güncelliğini koruyan mekân ve yer kavramları, her daim birbirleriyle hem etken hem edilgen olarak mutlak bir etkileşim içinde bulunmakla birlikte 'yer' kavramı ayrıca "bir tarafta belli bir coğrafyaya özgü toplumsallaşmanın beraberinde getirdiği örf, adet, alışkanlık ve ritüellerin izlerini taşırken, diğer tarafta kişinin bulunduğu mekânı bireysel deneyimlerle içselleştirmesine, orada güven ve aidiyet duymasına da imkân verir"3

Yer kavramıyla tarih boyunca farklı coğrafya ve disiplinlerde (felsefe, sosyoloji, antropoloji, etnografi, mimarlık vd.) farklı nitelik ve yaygınlıkla karşılaşılır. Kavramın gündelik hayatta da çok yaygın kullanım alanları vardır. Yer kavramı gerek sözlük anlamıla, gerek 'yer etmek', 'yerini bulmak', 'yersiz yurtsuz kalmak' gibi dilimize yerleşmiş deyimlerdeki mecazi anlamlarıyla çok geniş bir anlama sahiptirł.

20. yüzyılın ikinci yarısı ile birlikte 'yer' kavramı temel bir düşünce sistemi olarak bağlı bulunduğu dönemsel olaylar ve gelişmelerin iki kutuplu karşılığında merkezi bir analitik biçeme sahip olduğunu bizlere göstermiştir. Bir tarafta kimliğe bağlı aidiyet ve ben merkezli ötekileştirici / taraflı bir dil imgesi, diğer tarafta ise 'yer'e ait deneyimlemelerin özneler için öneminden bahsedilmektedir...Yer oluşumunda sorgulanan en önemli kavramların başında kimlik ve özne arasındaki konumlandırma süreçleri gelmektedir ${ }^{5}$.

$\mathrm{Bu}$ süreçle birlikte hemen hemen tüm alanlarda başlayan yeni tip yaşam biçemi, dünya medeniyetleri üzerinde oluşmaya başlayan küreselleşme düzenine bağlı tek tip yaşam arketipini geçerli kılmış olup bu durum moderniteye kadar oluşan çoklu medeniyet çeşitliliğini olumsuz yönde değiştirerek modernite ile birlikte insanları ve coğrafyaları bağıl bir mutlakıyete öteleyen muğlaklıkta konumlandırarak onları zorlama bir modele mahkûm etmiştir. "Modernitenin ve küreselleşmenin tetiklediği yeni sosyo-kültürel ve siyasi dinamikler, medeniyet gibi büyük kavramları yetersiz, yersiz yahut işlevsiz hale getirmektedir"6. Buna karşın küreselleşme aynı zamanda medeniyet kavramının önemini de artıran bir etkiye sahip olarak öznel kimliklerin kendi

3 Marc Auge, Yok Yerler, (Çev. Turhan Ilgaz, Çev. Güncelleme. Ergun A. Akça, Arbil Ötkünç) Daimon Yayınları, İstanbul 2016, s. 8.

4 a.g.e, s.9.

5 a.g.e, s.8.

6 İbrahim Kalın, Barbar Modern Medeni, İnsan Yayınları, İstanbul 2018, s.10. 
belleklerine olan bağl1lığını da güçlendiren bir tezat da oluşturmaktadır?

Moderniteden sonra değişmeye başlayan yeni dünya düzeni bizlere göstermiştir ki üzerinde büyük değişimlerin meydana geldiği mekân ve yer kavramlarının toplumsal medeniyetlere göre şekillenmesinde 20. Yüzyılın en büyük etkenleri arasında olan milliyetçilik ve etnisite gibi değerlerin büyük etkileri olmuş ve bu bağlamda çeşitli kırılmalar yaratmıştır. Bu kırılmalar özellikle küreselleşmeyle birlikte sömürgecilik faaliyetlerini de başlatmış buna karşılık aynı zamanda sömürgeciliğe dayalı çok farklı rejim sistemlerini de ortaya çıkarmıştır. Bu yönetim biçimleri bazen "De Facto" (fiili) ve "De Jure" (hukuki) analitiklere göre şekil alan; bazen de özerk statülerde yönetim biçimleriyle geliştiren yeni tip bir yönetim modelleriyle toplumları baskı altına almıştır. Fakat bu post dönem aynı zamanda kendi içerisinde paradoksal bir retoriği de içererek ulusların kendi kaderlerini belirleme ve tayin etme dürtüsünü de harekete geçirmiş sömürge tipi yönetimlerden bağımsız, egemen ve üniter devletlere geçen özgürleşme döneminin de yolunu açmıştır.

Özellikle İkinci Dünya Savaşı ile artık daha da görünür bir hal alan bu süreçte sömürgecilik tasfiye olmaya başlamış ve Asya ile Afrika' daki pek çok sömürge ya da özerk devlet bağımsızlaşma yoluna girmişlerdir. Bu durum ortaya üçüncü dünya adı verilen kavramı ortaya çıkarmıştır. Modernitenin devamı şeklinde post bir uzamda fiili bir yapı olarak betimlenen üçüncü dünya kavramı özellikle postmodernite ile birlikte coğrafyalar üzerinde gerek teknolojik olarak, gerekse sanayi vb. bakımdan gelişimini geç tamamlayan ya da tamamlamakta olan her iki dünya savaşından sonra oluşan soğuk savaş ile küresel, kapitalist ve emperyalist devletlerin ortaya çıkardığı bir yapı aidiyeti olmuștur. Aslında üçüncü dünya kavramı bir bakıma bağıl olarak özerk, yarı özerk ya da uydu devlet gibi tanımlamaların da farklı bir adı olarak tarif edilebilir.

Sömürgecilikle emperyalizm deyimleri arasında kesin bir ayrım yapılamamıştır... $1945^{`}$ te Birleşmiş Milletler kurulduğu zaman 53 - 54 üyesi vardı. Bugün ise 151 üyesi vardır. Yirmi yıl önce (1980 sonları) Afrika'da bağımsız devlet sayısı beş veya altı idi, bugün 51 olmuştur. Bu devletlerin çoğunluğu 1960 'dan sonra bağımsız olmuştur. Asya ve Ortadoğu da aynı şekildedir?

\section{Tarihsel ve Siyasal Perspektifte Kıbrıs}

Geçmişten günümüze her daim önemini koruyan bir ada olan Kıbrıs "tarih boyunca pek çok uygarlığın yaşadığı...Akdeniz'in kuzeydoğusunda $34^{\circ} 33^{\prime}$ kuzey enlemleri ve $32^{\circ} 20^{\prime}$ ile $34^{\circ} 35$ doğu boylamları arasında yer almaktadır. $9251 \mathrm{~km} 2$ yüzölçümü ile Akdeniz'de...üçüncü büyük adadır" ${ }^{10}$ Kıbrıs'ın bulunduğu konum itibarıyla Güney Anadolu ve Suriye gibi bölgelerine olan hâkimsel özelliği bu bölgeleri kontrolü altında tutan devletlerin Kıbrıs’ta egemenlik kurmalarında en önemli unsurlardan biri olmuştur ${ }^{11}$. "Ada'nın Akdeniz ticaret yolları üzerinde bulunuşu, yanı sıra Anadolu, Mezopotamya, Mısır, Helen, Roma gibi medeniyet bölgeleri arasında yer alışı da, eski

$7 \quad$ a.g.e, s.10.

8 Fahir Armaoğlu, 20. Yüzyll Siyasi Tarihi (1914 -1995), Kronik Kitap, İstanbul 2018, s. 320.

9 a.g.e, s.67.

10 Bedevi'den akt. Dilek Yiğit Yüksel, Kıbrıs Cumhuriyeti’nin Kuruluşs Süreci ve Sorgulanan Varlı̆ğ (1878 - 1964), Berikan Yayınevi, Ankara 2018, s. 17

11 Erol Mütercimler, Satılık Ada Kıbrıs, Alfa Kitap, İstanbul 2017, s.91. 
devirlerden bu yana pek çok devletin Kıbrıs'a egemen olmak için çeşitli girişimlerde bulunmasına yol açmıştır" "(Görsel 1).

16. yüzyılın ikinci yarısında çok önemli bir konumda bulunan Osmanlı Devleti o döneme kadar Venediklilerin elinde bulunan ${ }^{13}$ Kıbrıs'1, bulunduğu coğrafi, stratejik ve jeopolitik konumu sebebiyle 1570 yılında fethetmiş ve adaya iç ve Güney Anadolu'dan nüfus taşınmıştır. Adada Osmanlı döneminde her dinsel topluluk ve halklar temsil edilme hakkına sahip olmasının yanında en huzurlu dönemini yine Osmanlı egemenliği altında sürdürmüştür. Kıbrıs Osmanlıların Çarlık Rusya'sı ile olan savaşı ve diğer siyasal ve askeri sorunlarının da etkisi ile ada 1878 'de yapılan anlaşma ile İngiltere'ye önce geçici olarak, daha sonra ise tamamen İngiliz yönetimine geçmiştir ${ }^{14}$. Armaoğlu'nun yukarıdaki değerlendirmesine göre tüm dünyayı etkisi altına alan bağımsızlaşma hareketleri bulunduğu konum itibariyle çok öneme sahip olarak hayati bir pozisyonda bulunan Kıbrıs'ta da benzer bir yapılanma yaşatmış ve İngiliz yönetimine karşı çeşitli ayaklanmalar başlamıştır.

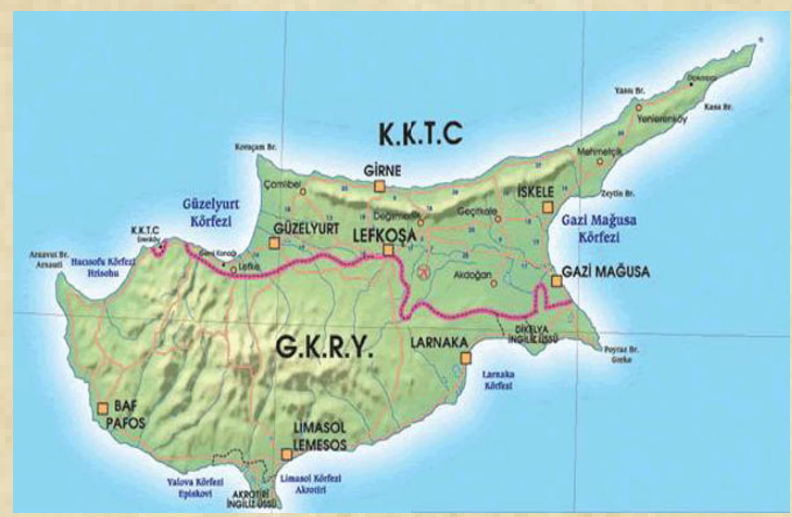

Görsel 1. Kıbrıs Haritası (1974 - günümüz) $)^{15}$

1878'den beri İngiliz sömürgesi olarak varlığını sürdüren Kıbrıs’ta başlayan halk hareketleriyle İngilizlerin adadaki hakimiyeti zorlu bir sürece girmiştir ${ }^{16}$. Adada bulunan iki toplumdan biri olan Rumlar 1948 yılında Enosis (Kıbrıs'ın Yunanistan'a bağlanması) yönünde tavır alınca ${ }^{17}$ Türklerde tek taraflı yanlı olan bu düşünceye karşı yönde görüş bildirerek kendi örgütlenmelerini hızlandırmışlardır ${ }^{18}$. Adada artan gerginlikler her geçen gün dozunu artırırken Rumlar İngiliz ve Türk hedeflerine yönelik eylemlerini, Türklerde kendi güçleri olan TMT: Türk Mukavemet Teşkilatını kurmuş; yaşanan bu durumlar İngiltere'nin adadaki statükosunu tehlikeye sokmuş ve adada Türk ve Rum topluluklar arasında yaşanan çatışmalarla birlikte İngiltere'nin ada üzerindeki meşruiyeti tehlikeye düşmüştür ${ }^{19}$.

\footnotetext{
12 a.g.e, s. 91.

13 Uçarol'dan akt. Erol Mütercimler, Satılık Ada Kıbrıs, Alfa Kitap, İstanbul 2017, s.93.

14 Erol Mütercimler, Satılı Ada Kıbrıs, Alfa Kitap, İstanbul 2017, s.93, 94 ve 98.

15 https://turkinfo.hu/wp-content/uploads/2019/12/kktc-haritasi.jpg Erişim tarihi: 10.04.2021.

16 Ali Balcı, Türkiye Dış Politikası, Alfa Kitap, İstanbul 2017, s.124

17 Akgün'den akt. Ali Balcı, Türkiye Dış Politikası, Alfa Kitap, İstanbul 2017, s. 124.

18 Bölükbaşı’ndan akt. Ali Balcı, Türkiye Dış Politikası, Alfa Kitap, İstanbul 2017, s. 124.

19 Ali Balcı, Türkiye Dış Politikası, Alfa Kitap, İstanbul 2017, s. 125.
} 
1950’li yılların sonlarına doğru toplumlar arasında artan şiddet olaylarına bağlı olarak Türkler, Yunanlılar ve İngilizler arasında artan olaylar hasebiyle ve de NATO'nun doğu Akdeniz'deki gücünü olumsuz etkilemesi gibi sebepler nedeniyle NATO ve ABD'nin de etkisiyle 1959 yllında sırasıyla Zürih ve Londra'da yapılan görüşmeler sonucunda İngiltere, Türkiye ve Yunanistan'ın garantörlüğünde bağımsız bir Kıbrıs Cumhuriyeti kurulmasına karar verilmiştir ${ }^{20} .1960$ yılında bir anlamda ortaklık cumhuriyeti olarak da anılacak olan bu devletin anayasal ve hukuki zemini İngiltere, Türkiye ve Yunanistan'ın garantisi altına alınmıştır ${ }^{21}$.

Kuruluşundan üç yıl geçmesine rağmen 1963 yılından sonra Cumhurbaşkanı Makarios üç devletin garantörlük esasına dayalı olarak kurulan Kıbrıs Cumhuriyeti anayasasında Türkleri adada hem azınlık statüsüne sokmak hem de yönetiminden tamamen uzaklaştırıp Akritas Planı çerçevesinde adayı Yunanistan'a bağlamak için pek çok hukuksuz girişimde bulunmuş ve insanlık dışı eylemlere başvurmuştur. Bu duruma seyirci kalmayan Türkler, kahramanca ve destansı olarak adadaki haklı davalarını savunarak kararlılıkla bu hukuksuzluğa karşı çıkmışlardır. 1974 yılına kadar uluslararası hukuka uygun tüm diplomasi yollarını deneyen Türkiye Cumhuriyeti ise haklı olarak garantörlük hakları çerçevesinde Birleşmiş Milletler müktesebatına da uygun olarak adaya 1974 yılında bir barış harekâtı düzenlemiştir ${ }^{22}$. Tüm bu olaylardan sonra Türkler adanın kuzeyinde sırasıyla otonom ve federe bir yönetim kurmuş ve 1983 yılında da bağımsız ve egemen Kuzey Kıbrıs Türk Cumhuriyeti'ni kurarak yoluna devam etmiştir. Kurucu cumhurbaşkanı ise Rauf Raif Denktaş’tır.

\section{Adanın Sosyolojik ve Tipolojik Tarihsel Medeniyet Dokümantasyonu Üzerine Kimlik Arketipi}

Coğrafi eksende düşündüğümüzde özellikle kıtaların kavşak noktasında konumlanması sebebiyle adeta bir gözlem simgesi olarak dünyanın en merkezi bölgesinde bulunan Kıbrıs adası bu yüzden üzerinde pek çok yaşayışın varlık gösterdiği bir konumda sayısız medeniye ev sahipliği yapmıştır. Bu bakımdan adanın medeniyet tipolojisi de demografik açıdan bu çok kültürlü katmanlarla birleşerek zengin bir bilince dayalı imge ve kültürlerin kozmopolit bir melezlikte şekil almasında etkili olmuştur.

20 Fahir Armaoğlu, 20. Yüzyll Siyasi Tarihi (1914 -1995), Kronik Kitap, İstanbul 2018, s. 407.

21 Ali Balcı, Türkiye Dış Politikası, Alfa Kitap, İstanbul 2017, s. 126.

22 Dilek Yiğit Yüksel, Kıbrıs Cumhuriyeti’nin Kuruluş Süreci ve Sorgulanan Varlığı (1878-1964), Berikan Yayınevi, Ankara 2018, s. 165 - 166. 
Kıbrıs'ta hakimiyet kurmuş olan devletler adanın nüfus yapısını, yerleşim yapısını, kültürünü ve ekonomisini şekillendirmişlerdir. Osmanlıların fethinden önce ada, Misırlılar, Hititler, Akdeniz Kolonileri (Akalar, Dorlar, Fenikeliler), Persler, Büyük İskender, Romalılar, Bizanslılar, İngilizler, Tapınak Şövalyeleri, Luzinyanlar, Cenevizliler, Memlukler ve Venedikliler tarafından idare edilmiştir ${ }^{23}{ }^{24}$.

Doğu Akdeniz hinterlandının merkezi ve kilit bir gözcü konumunda bulunan Kıbrıs adası bağlı bulunduğu konum itibariyle detaylarını aşağıda verdiğimiz medeniyet kronolojisine göre çok farklı medeniyetlerin, devletlerin dinsel, yönetimsel, siyasal ve günlük yaşamda dinamik formlar ile harmanlanmış bir biçimde ada üzerinde yaşadığı gözlemlenmiştir. Bu bakımdan adada gelişen yaşam kültüründe çoklu dinamiklerin aktif olarak gözlemlendiği yaşam dizgeleri tüm mekanlar üzerinde bu zenginlikle harmanlanmıştır.

Ada, yukarıda da belirttiğimiz üzere pek çok medeniyetin kendi kültürlemesini yaptığ1 bir konumdayken üzerinde egemenliği uzun süre elinde bulunduran Osmanlı İmparatorluğu, yönetimde bulunduğu yıllarda adanın sosyo - kültürel dokusuna bağlı olarak hiçbir medeniyet ve dinsel topluluk üzerinde zorlama bir baskı unsuru yaratmamış ve buna ek olarak millet politikası çerçevesinde her toplumun temsil yetkisi olduğu ve özgürce yaşadığı bir yapısal yönetim anlayışını adada hâkim olduğu yıllarda sürdürmüştür ${ }^{25}$. Fakat bu durum adanın İngiliz yönetimine geçmesiyle birlikte değişerek İngiliz hegemonyasının adada geçerli bir anlayış oluşturmasına sebebiyet vermiștir.

Siyasal detaylarını önceki bölümde verdiğimiz Kıbrıs, İngiltere, Türkiye ve Yunanistan’ın yaptıkları görüşmeler sonunda 1960 yılında İngiliz yönetiminden çıkarak kurulan ortaklık cumhuriyetiyle (Kıbrıs Cumhuriyeti) çok az bir süre ortak statü çerçevesinde yönetilmiş fakat Rumların adada daha fazla söz sahibi olmak istemesi ve tek bir medeniyet etrafinda adaya hâkim olma isteği, Türkler üzerinde ciddi anlamda bir baskı unsuru oluşturmuştur. Bu sebeple 1974 yılında adadaki her iki toplum Kuzey ve Güney şeklinde iki ayrı yönetime ve bölgeye ayrılarak Kuzeyde Türkler, Güneyde ise Rumların yaşadığı bir yapıya geçiş yapmış ve bölge Birleşmiş Milletler tarafından denetimi yapılan Yeşil Hat ile ayrılarak iki ayrı toplumlu ve iki farklı düzene bağlı olarak alan hakimiyetinde yaşamaya başlamışlardır. Bu durum sebebiyle mimari, örfi, gündelik vb. kimliksel bellek mekanizmaları da ayrılan bu sistem değişimine göre yeniden şekil almıştır. Kıbrıs'ın bu sebeplerle değişen yapısı oluşan yeni uluslararası siyasi durumlar ve dengeler sebebiyle geçmiş düzendeki ekonomik yapısında da büyük değişiklikler yaparak adada çok farklı çıktılara bağlı yeni tip ekonomi modellerine geçiş yapılmıştır (Turizm, off -Shore vb.). 1974 yılında

23 Ayrıca Bkz. Kıbrıs’ta kurulan medeniyet kronolojisi: “M.Ö.7000 - 3000 Yeni Taş Devri, M.Ö.3000 1500: Bronz Çağı, M.Ö. 1500 -1450: Eski Mısır Dönemi, M.Ö. 1320 - 1200: Hitit Dönemi, M.Ö. 1200 - 1000 - 710: Eski Mısır Dönemi, Fenikeliler Dönemi, Kıbrıs Şehir Krallıklarının Kurulması, M.Ö. 710 - 609:Asurlular Dönemi, M.Ö. 609 - 525: Misır Dönemi, M.Ö. 525 333: İran Pers Dönemi, M.Ö. 411 333: Pers ve Eski Yunan(Helen) Dönemi, M.Ö. 294 - 58: Ptolemiler Dönemi, M.Ö. 58 - M.S. 395: Roma Dönemi, M.S. 395 - 1190: Bizans Dönemi, 1190 - 1191:Haçlılar Dönemi, 1191 - 1489: Lüzinyan Dönemi, 1489 - 1571: Venedik Dönemi, 1571 - 1878: Osmanlı Türk Dönemi, 1878 - 1960: İngiliz Dönemi, 1960 - 1974: Kıbrıs Cumhuriyeti, 1974: Kıbrıs Barış Harekatı, 1974 - 1983: Kıbrıs Türk Federe Devleti, 1983 :

Kuzey Kıbris Türk Cumhuriyeti” http://users.metu.edu.tr/birten/tarih.html, Erişim tarihi: 15.04.2021

24 Alasya’dan akt. Dilek Yiğit Yüksel, Kıbrıs Cumhuriyeti’nin Kuruluş Süreci ve Sorgulanan Varlığı (1878 - 1964), Berikan Yayınevi, Ankara 2018, s.17. 
başlayan iki farklı yaşam medeniyeti adadaki birleşik Kıbrıs oluşumuna bağlı aidiyetler üzerinde de farklılıklar yaratmış ve bu durum her geçen gün toplumların kendi bölgelerindeki ortak mekânsal birliktelikten iki toplumu iyiden iyiye birbirinden ayırmıştır. Fakat yine de bu gelişmelere rağmen günümüzde adanın ortak Kıbrıs arketipi üzerinde her iki tarafta da hala ayakta kalabilmiş pek çok camii, tekke, türbe, kilise, çeşme, kemer, hamam, manastır, katedral ile diğer toplumsal, kültürel ve dinsel yaşama ait simgeler adanın ortak yaşamdaki bellekleri olarak varlıklarını korumuşlardır. Buradaki yapıların bu çoklu medeniyete bağlı kimlik aidiyeti aslında Schlesinger'in (2011) kimlik betimlemesinde ifade ettiği kolektif bir bütünde "bütün kimlikler, bir toplumsal ilişkiler sistemi içinde oluşur ve birbirlerini karşılıklı tanımaları gerekir. Kimlik...bir 'nesne' olarak değil, 'bir simgeler ve ilişkiler sistemi' olarak düşünülmelidir”’26 ifadesindeki gibi bir denklemde oluşmuştur.

Kıbrıs'ta geçmiş dönemlerden günümüze kadar kalabilmiş olan ve bileşik kimlik arketipinde adanın çok çeşitli medeniyet kültüründe yapılan farklı dinsel ve kültürel mekanlara günümüzde de rastlamaktayız. Bu yapılar özellikle farklı toplumsal katmanlara ve inanış şekillerine göre yapılmış olup ortak Kıbrıs belleğindeki imgeleri oluşturan yapılar olması bakımından önem arz etmektedir. Bu yapılardan günümüzde hala ayakta kalanlar arasında; Hala Sultan Tekkesi ve Camii (Larnaka - Güney Kıbrıs), Azize Anna Kilisesi (Gazimağusa - Kuzey Kıbrıs), Bellapais Manastırı (Girne - Kuzey Kıbrıs), Gazi Paşa Çeşmesi (Kubbeli Çeşme) (Limasol - Güney Kıbrıs), Ebubekir Paşa Su Kemerleri (Larnaka - Güney Kıbrıs) (Bkz. Görsel 2), Othello Kalesi (Gazimağusa - Kuzey Kıbrıs) (Luzinyan dönemi) gibi... daha pek çok sayıda tarihi yapı çok kültürlü yaşamın parçasını oluşturan en önemli değerler yukarıda belirttiğimiz ortak yaşamdaki ayrı kültürel dinamikler olarak varsayılabilir. ${ }^{27}$

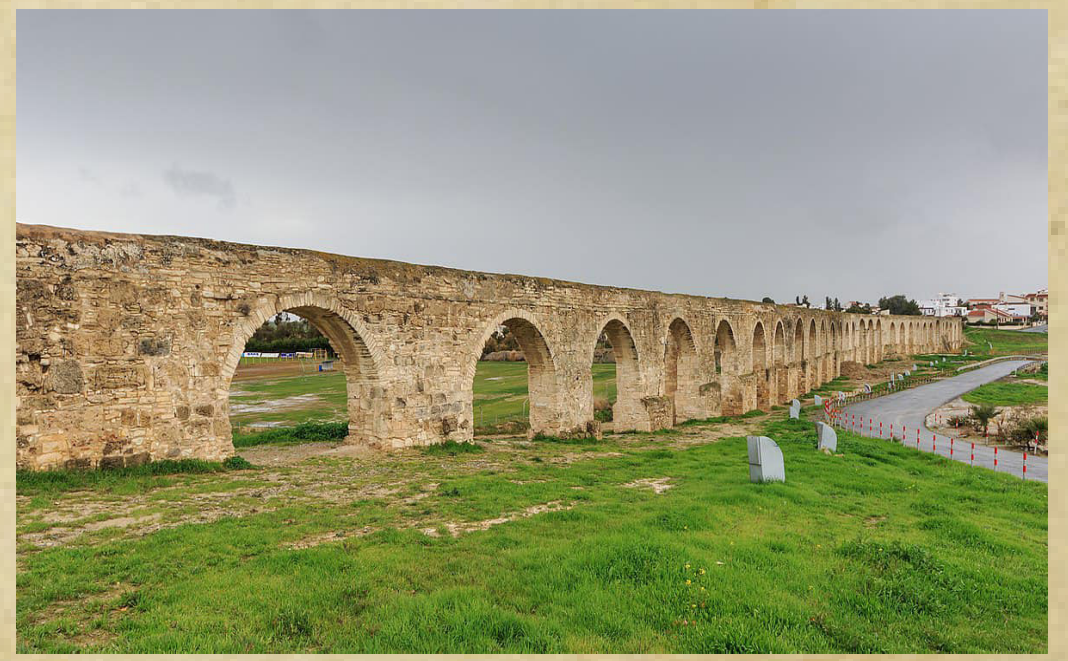

Görsel 2. Ebubekir Paşa su Kemerleri, Larnaka - Güney Kıbrıs ${ }^{28}$

26 Schlesinger'den akt. David Morley \& Kevin Robins, Kimlik Mekanları, (Çev. Emrehan Zeytinoğlu) Ayrıntı Yayınları, İstanbul 2011, s.74.

27 Bu yapılar Oktay Aslanapa, Kıbrıs’ta Türk Eserleri, Kültür Bakanlığı Yayınları, İstanbul 1975 adlı kitap ve https://www.ayazrentacar.com/kibris-tatil-rehberi/kibrista-kilise-katedral-manastir adlı internet kaynağından derlenmiştir. Erişim tarihi: 15.04.2021 http://www.evkaf.org/site/sayfa.aspx?pkey=1195, Erişim tarihi: 17.04.2021 


\section{Mekânsal Bir "Yer" Dinamiği Olarak Eski Kıbrıs Poetikasının Kalıcılığı: Kapalı Maraş Örneği}

1974 yılı Kıbrıs tarihi açısından belki de çok büyük bir kırılmanın yaşandığı, bir anlamda Türk ve Rum toplumlarının adada ayrı bölgelerde yaşamlarını sürdürmeye başladıkları bir yıl olmuştur. 1975 yılında yapılan "Nüfus Mübadelesi Anlaşması" ile karşılıklı olarak kuzey ve güney bölgelerine göçler başlamış Türkler adanın kuzey bölgesine Rumlar ise güney bölgesine geçmiştir ${ }^{29}$. Bu tarihten sonra Türkler adanın kuzeyinde $(\% 36,5 \text { 'inde })^{30}$, Rumlar ise güneyde (\%63,5'lik) bir bölgede yaşamlarını sürdürmeye başlamışlar ve iki toplumlu farklı bölgelerde milliyet, siyaset ve din anlayışında meşruiyetlerini devam ettirmişlerdir. Her iki toplum yıllardır Birleşmiş Milletler'in arabuluculuğunda yapılan görüşmelere rağmen Kıbrıs sorunu üzerinde henüz bir anlaşmaya varamamıştır. Bu sebeple Türkler kuzeyde, Rumlar da güneyde kendi kültürel kimliğine dayalı yaşamlarına devam etmişlerdir. Aradan geçen uzun yıllar sebebiyle adadaki ortak Kıbrıs dokümantasyonuna ait ortak bilince dair simgelemler de yavaş yavaş etkinliğini yitirmeye başlamış bu yüzden her iki toplum bağlı olduğu milliyetler esasında işleyen devlet mekanizmalarına göre değişen ve gelişen aidiyet çerçevesi içinde örüntü oluşturmaktadırlar. Bu durum tıpkı Edward W. Soja'nın Postmodern Coğrafyalar adlı kitabında bahsettiği "Yeniden Yapılanma Kavramı" üzerine yapmış olduğu çıkarımlardaki gibi “...en geniş anlamıyla, uzun vadeli eğilimlerde bir kırılma değilse bile bir 'fren' anlamı taşır ve toplumsal, iktisadi ve politik yaşamda önemli ölçüde farklı bir düzene doğru yaşanan geçişi ifade eder"31. Buradaki fren mekanizması ortak kimlik tasavvurunu ortadan kaldırarak her iki toplumu iki farklı yaşam arketipi üzerinden tanımlayan bir ayrıma götürmüştür.

\section{Kapalı Maraş}

"Çevremi hoyratça saran sandıklarda aranıp duruyorum

Karanlıkları altüst ederek

Artık bu dünyaya ait değilmiş gibi duran

Derin mi derin kutuların içinde" ${ }^{32}$

Gaston Bachelard'ın "Mekânın Poetikası" adlı eserinde geçen bu şiir, mekanların metaforik bir biçimde bağlamsal paradigmalara bağlı olarak tıpkı bir sandık içerisindeymişçesine yaşanmışlıkları muhafaza ettiğini bizlere çekmece, dolap, köşe, mahzen, iç ve dış gibi temelde ev mekanlarını belleğin sınırsız analitiği üzerinden bizlere betimlemiştir. ${ }^{33}$ “....Bachelard'a göre ev insanı fırtınalar karşısında ayakta tutar, yaşam boyunca kazanılmış şeylerin korunmasına imkân

29 Anıl Çeçen, Kıbrıs Çıkmazı, Astana Yayınları, Ankara 2018, s.412. Bu anlaşmada ayrıca kuzey bölgesinde kalmak isteyen Rumlar için bir serbestlik tanınmaktadır (A.g.e. 412).

30 https://www.aa.com.tr/tr/ulke-profilleri/kuzey-kibris-turk-cumhuriyeti-kktc/901503 ,Erişim tarihi: 08.04.2021

31 Edward W. Soja, Postmodern Coğrafyalar (Eleştirel Toplumsal Teoride Mekânın Yeniden İleri Sürülmesi) (Türkçesi: Yunus Çetin), Sel Yayıncılık, İstanbul, 2017 s. 213.

32 Supervielle'den akt. Gaston Bachelard, Mekânın Poetikası (Çev. Alp Tümertekin), İthaki Yayınları, İstanbul 2020, s.120.

33 Gaston Bachelard, Mekânın Poetikası (Çev. Alp Tümertekin), İthaki Yayınları, 2020: Genel çıkarım. 
verir..."34. Bu bir anlamda temel yaşam analojilerinin doğrudan bağlantılı olduğu koruyucu bir tasvir olarak şekillenen aidiyet kavramlarına vurgu yapmaktadır. "Gündelik hayat dilinde yarattı̆g çağrışımlar düşünüldüğünde, 'aidiyet' her şeyden önce 'ev'le bağlantılı bir kavram. 'Ev', mekânsal ve toplumsal olarak kendimizi 'ait' hissettiğimiz yerdir. Burada 'ev’i fiziksel bir yapı olarak değil, yarattığı simgesel çağrışımlar anlamında düşünmeliyiz" 35 ."Evimiz, mekânsal, varoluşsal ve kültürel olarak ait olduğumuz, parçası olduğumuz topluluğun, ailemizin ve sevdiklerimizin yaşadığı, kendi kökenlerimizi bulacağımız, dünyanın başka bir yerindeyken geri dönmeyi özlediğimiz yerdir"36. Kapalı Maraş’taki halihazırda oluşan görüntüler de belki de bu betimlemedeki gibi yaşanmışlara ait izlerin net bir şekilde görüldüğü dondurulmuş ve kozmopolit bir ev statüsündeyken zamanla köhneleşmiş bir ev görünümüne bürünmüştür.

Kapalı Maraş aslında Wright'ın kolektif kimliğe dayanan ortak bilince bağlı belleklerin ${ }^{37}$ ortak geçmişteki anılarının toplandığı bir yer olması bakımından günümüzde bu kolektif yaşama dair izlerin görsel hafizalarda donakalmış noktaları gibidir ${ }^{38}$. Maraş'ta oluşan bu durum eski yaşanmışlıklara dair oluşan anıların tıpkı eski bir sandıktaymışçasına biriktiği ve içinde pek çok hayatın olduğu kolektif bir bellek tipolojisi gibi gün yüzüne çıkmayı bekleyen bilinç uzamlarıdır. Kıbrıs'ın Gazimağusa bölgesinde bulunan Maraş, bugün giriş ve çıkışların yasak olduğu 1974 yılına kadar dünyanın en önemli turizm bölgelerinin başında gelmekteydi. Burada çok sayıda ulusal ve uluslararası düzeyde oteller, alışveriş merkezleri yanında tarihi dokuda pek çok yapı ve kalıntılarında olduğu bölge 1974 yılında yapılan barış harekatıyla birlikte Kuzey Kıbrıs Türk Cumhuriyeti'nin egemenlik alanına girmiştir. Bölge içerisinde Birleşmiş Milletlere ait bir bina, bir adet askeri orduevi, öğrenci yurdu ve telekomünikasyon binası ${ }^{39}$ dışında giriş çıkışların yasak olduğu Maraş’1n bir bölümü 47 yıldır kapalı olan bir bölge statüsüne dönüşmüştür ${ }^{40}$ (Bkz. Görsel 3).

34 Bachelard'dan akt. Yaşar Çabuklu, Uzam ve Kötülük, Everest Yayınları, İstanbul 2006, s. 33.

35 Asuman Suner, Hayalet Ev (Yeni Türk Sinemasinda Aidiyet Kimlik ve Bellek), Metis Yayınları, İstanbul 2015, s. 16,17.

36 Hedetoft ve Hjort'dan akt. Asuman Suner, Hayalet Ev (Yeni Türk Sinemasinda Aidiyet Kimlik ve Bellek), Metis Yayınları, İstanbul 2015, s.17

37 Wright'dan akt. David Morley \& Kevin Robins, Kimlik Mekanlarl, (Çev. Emrehan Zeytinoğlu) Ayrıntı Yayınlar1, İstanbul 2011, s.74.

38 Schlesinger'den akt. David Morley \& Kevin Robins, Kimlik Mekanları, (Çev. Emrehan Zeytinoğlu) Ayrıntı Yayınları, İstanbul 2011, s.74.

39 Bkz. Bölgede giriş yapılan yerler için :http://www.gazetevatan.com/maras-neden-kapatildi-kapalimaras-hikayesi-nedir-46-yildir-kim-1346792-gundem/ Erişim tarihi: 11.04.2021

408 Ekim 2021 tarihi itibariyle KKTC'nin aldığı bir kararla bölgenin bazı yolları ile deniz kıyıları halkın kullanımına açılmış olup bölgede yer alan mülklerin durumu taşınmaz mal komisyonu tarafından gerekli envanter ve kayıtları ile tespit edilmektedir. Ayrıca Bkz. http://www.tamk.gov.ct.tr/index.html Erişim tarihi: 11.04.2021 ve http://www.gazetevatan.com/maras-neden-kapatildi-kapali-maras-hikayesinedir-46-yildir-kim-1346792-gundem/, Erişim tarihi: 11.04.2021 


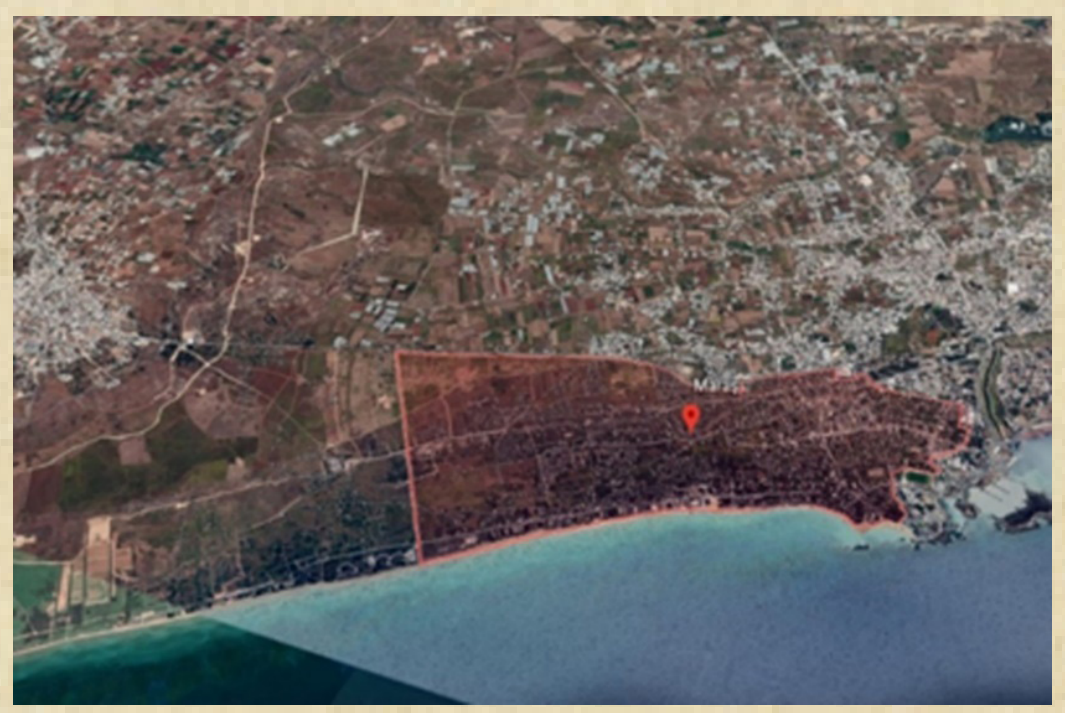

Görsel 3. Kapalı Maraş, Gazimağusa - Kuzey Kıbrıs Türk Cumhuriyeti ${ }^{41}$

1974 yılından sonra Kuzey Kıbrıs Türk Cumhuriyeti’nin egemenliği altında olan bölgenin insansızlaştırılmış yapısı, zamanlä tüm mekanlara ait bileşkelerin işlevselliğini yitirmesine ve anlamsızlaşasına yol açmıştır. Bu bakımdan mekanlar giderek çürümeye başlamış ve yapılar üzerinde oluşmaya başlayan korozyon zamanla bölgenin tamamının ıssız bir görünüme sahip bir alan olarak "tekinsiz" bir hal almasında etken olmuş ve ürkütücü manzaraların oluşmasını sağlamıştır. Bu durum zamanla bellek ve bilinç mekanizmalarını da harekete geçirerek bölgenin günden güne oluşan ıssız durumu tekinsizlik hissinin daha da artmasına sebebiyet vermiştir. Bölgedeki yapıların zamana bağlı değişim çizgisi yalnızlığa dayalı soyut, fantastik ve felsefi ögelerin de bağlamsal bir algoritma içinde tıpkı Ernest Jentsch'in deyimiyle “bir 'şey' ya da hadisenin tekinsizliği izlenimi nedeniyle bütünleşmiş bir oryantasyon eksikliğini ifade eder" ${ }^{2}$. Yine Jentsch'e göre (2019) tekinsizlik hissinin oluşması için aşinalığın olmadığı bir belirsizlik durumunun olması başı başına yeterlidir $^{43}$. Maraş bölgesinde de aynı şekilde benzer bir durumdan bahsetmek kuvvetle muhtemel bir çıkarımı ortaya koymaktadır. Bölge, 47 yıldır içinde bulunduğu durumdan ötürü 1ssız kalması sebebiyle içerisinde çok bilinmeyenli denklemlerden oluşan soru işaretlerini bünyesinde barındıran belirsizliklerle doludur. Bu bakımdan Maraş içerisindeki bu bilinmezliklere bağlı durumu, tıpkı Jentsch'in yukarıdaki ifadesinde geçen belirsizlikler ve olağan dışı durumlar ifadesindeki gibi ortaya psikotip bazı kaygıları tümel bir tekinsizlik içerisinde gözlemlenen yerlerden oluşmaktadır. Bunda özellikle detaylarına aşağıdaki fotoğraflarda da görebileceğimiz şekilde mekanların öldüğ̈̈ ve buna karşın doğanın sürdürülebilir bir yapıda olmasına karşın mekanla bütünleşerek onun da

41 https://earth.google.com/web/search/kapal\%c4\%b1+mara\%c5\%9f/@35.10378961,33.95839446,12.780181 4a,9508.92869027d,35y,-109.92871921h,44.99999747t,0r/data=CnkaTxJJCiUweDE0ZGZjODZmMzU2Z WJjMTU6MHg3NzcwMTRjNWYxOTZiZjVjGfPHtDaNjUFAIeoQ7oRN-kBAKg5rYXBhbMSxIG1hc mHFnxgCIAEiJgokCYutPSGhnEFAEWjA9ZJleUFAGYtgAV_WHEFAIWbnrGEd6kBA Erişim tarihi: 11.04.2021

42 Jentsch Ernest ve Simund Freud, Ernest Jentsch:Tekinsizliğin Psikolojisi Üzerine, Sigmund Freud: Tekinsizlik Üzerine (Çev. Hakan Şahin), Laputa Kitap, İstanbul 2019, s.12. a.g.e, s. 14 . 
öldügü çıkarımını yapmaktayız. Bu aslında Jentsch'in “...bir cesedin, ölü kafasının, iskeletlerin vb. şeylerin insanda yarattığı korku, bilinmeyen bir canlıya ilişkin akla gelen düşüncelerin bu gibi şeyleri anımsatıyor 'olmasıyla açıklanabilir. Korkunun etkisiyle bilince yansıyan düşünce, görüntüyü zihinde canlandırır ve böylece sözünü ettiğimiz ruhsal çatışmanın ön koşulu da olmuş olur" ${ }^{44}$ ifadesindeki durumla benzer özellikler taşımakta olup bu açıklamadan da anlaşılacağı üzere Maraş’ta da yıllardır süregelen bu ölüm sessizliği tüm mekanlar için herhangi bir 'ceset' tanımı ile eş bir benzerlik yaratmakta ve insanın çevresinde zihinsel bir egemenlik kurma dürtüsü ile alakalı olarak bölgenin bu bilinmezliği üzerindeki algı insanların belleklerinde belirsizlik yaratarak tekinsiz bir durumda konumlanmasına sebebiyet vermektedirr ${ }^{45}$ (Bkz. Görsel 4).

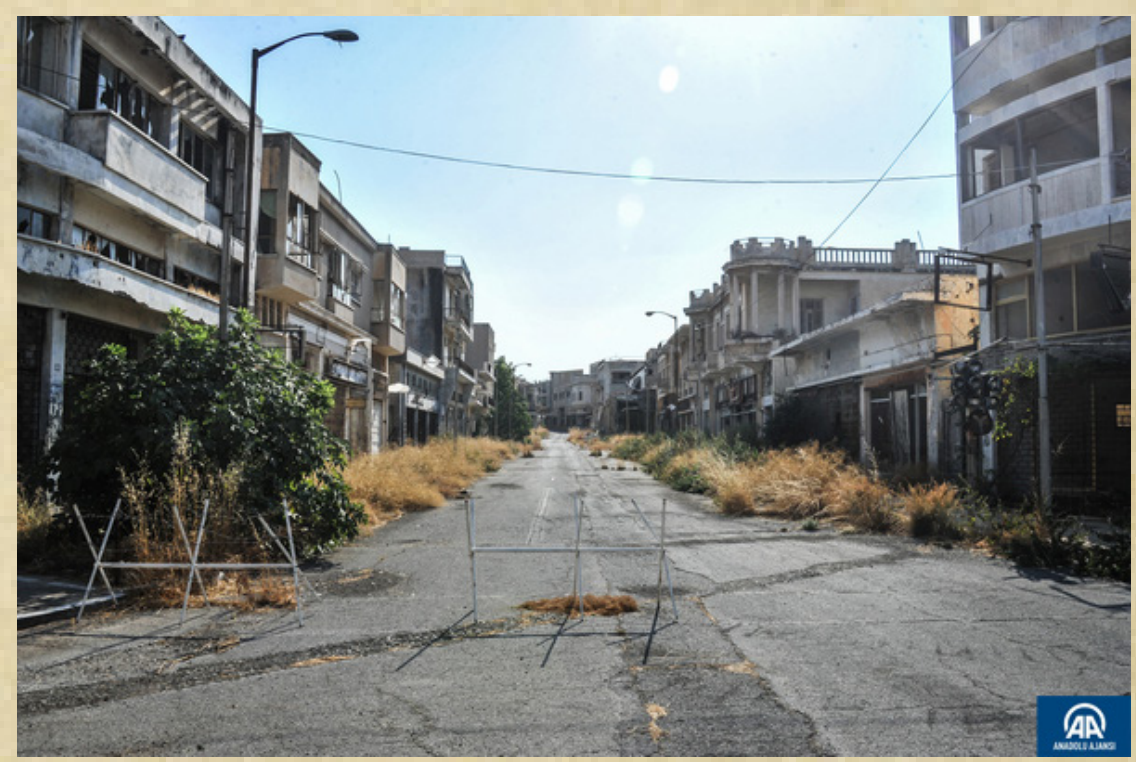

Görsel 4. Kapalı Maraş Bölgesi ${ }^{46}$

Aşağıda yer alan Kapalı Maraş görsellerine detaylı olarak baktığımızda mekanların tümündeki dinamik yaşanmışlıkların bir süre sonra belirli durağanlık içerisinde uzunca bir süre donmuş şekilde kaldığı görünmektedir. Bu bakımdan fotoğraflardaki tarih en son 1974 yılına işaret ederken o ana dair Birleşik Kıbrıs yapısındaki mekânsal mimari ve yaşayış düzeninde mündemiç olarak duran tümel öz değerlerin yapısal tarzdaki betimlemelerini görmekteyiz. Bu kapsamda alan üzerinde bulunan tüm toplumsal mekanlara ait yapılar imgesel olarak bilinçaltını harekete geçirecek cinste bir algoritmaya insanları zorlamakta ve bu durum tıpkı Lefebvre'nin (2019) 'Mekanın Üretimi' kitabında "Mutlak Mekandan Soyut Mekana" başlığı altında tarif etmiş olduğu çeşitli süreçlerden geçmiş biyomorfik ve antropolojik bir kazı olarak toplumsal mekanların hiçbir zaman yok olmayacağını, varlığın sadece iz ya da kalıntı olarak kalmadığını öncesi ve sonrasında da bir dayanak olarak kaldığını göstermektedir ${ }^{47}$ (Bkz. Görsel 5).

44 a.g.e, s. 28.

45 a.g.e, s. 28.

$46 \mathrm{Bu}$ fotoğrafın tüm hakları Anadolu Ajansı'na ait olup gerekli telif izinleri alınarak yayımlanmıştır. (Fotoğraf: Kültür ve Turizm Bakanlığı) Kod: AA - 19166357 Erişim Linki: https://www.anadoluimages. com/p/ersoy-kktcde-kapali-maras-bolgesini-inceledi/16816167 Erişim tarihi: 11.04.2021

Henri Lefebvre, Mekânın Üretimi (Türkçesi: Işık Ergüden), Sel Yayıncılık, İstanbul 2019, s.241. 


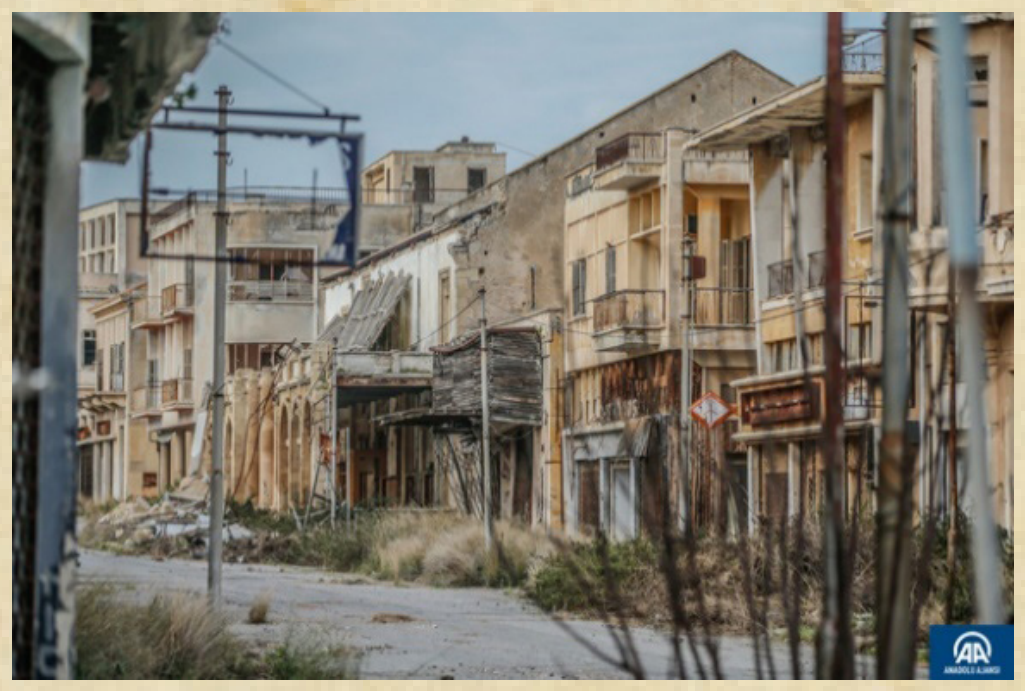

Görsel 5. Kapalı Maraş Bölgesi ${ }^{48}$

Kapalı Maraş, üzerinden geçen uzun yılların etkisi ile bölgedeki tüm elemanlar üzerinde yıkıcı bir güce sahip olan yalnızlığın getirmiş olduğu ölüm sessizliğinde çürüyen bir haldeyken bu mekanlar üzerinde belleğe dayalı bilinç mekanizmalarının izlerinin yavaş yavaş yok olmaya başladığı bir sürece doğru girmiştir. Bu süreçte doğal olarak bölgenin tekinsiz bir hal almasında büyük etken sahibi olurken bir yandan da doğa üzerinde bir müdahale olmayan ayrıcalıkta doğa ile bütünleşik bir hal almış ve oda bir anlamda ölüm sessizliğinde renksiz ve soluk olarak gelişimini sürdürmüştür. Buradaki bu ölüm durumu bölgenin bir anda terkedilme hissiyatı ile yalnızlaşmasının ortaya çıkardığı bir durum sebebiyle tıpkı Lefebvre'nin (2019) doğa betimlemesinde bahsettiği doğanın insan ile aynı hedefte bir yaşam mekanizmasında olmadığını ve doğadan söz eden kimselerin doğanın kendiliğindenliğini kabul etmesi gerektiğini betimler ${ }^{49}$. Kapalı Maraş’ta aynı olağan akış içerisinde bir süreç ile doğa katmanları varlıklarını geliştirerek sürdürmekte olup bu katmanlar mekân üzerinde günden güne baskınlığını artırarak yapıların kimliklerini kaplamaya başlamış ve bir anlamda insan yerine kimlik bulmuş birer organizmaya dayalı alegorik bir anlama sahip olmuştur ${ }^{50}(B k z$. Görsel 6).

48 Bu fotoğrafın tüm hakları Anadolu Ajansı’na ait olup gerekli telif izinleri alınarak yayımlanmıştır). (Fotoğraf: Muhammet Fatih Oğraş) Kod: AA - 22617396 https://www.anadoluimages.com/p/kapalimaras-46-yilin-ardindan-kademeli-olarak-aciliyor/20572983, Erişim tarihi: 11.04.2021

49 Henri Lefebvre, Mekânın Üretimi (Türkçesi: Iş̧1k Ergüden), Sel Yayıncılık, İstanbul 2019, s.97.

50 Bölgede halka açılan alanlar için bkz. http://www.gazetevatan.com/maras-neden-kapatildi-kapalimaras-hikayesi-nedir-46-yildir-kim-1346792-gundem/ Erişim tarihi: 11. 04.2021 


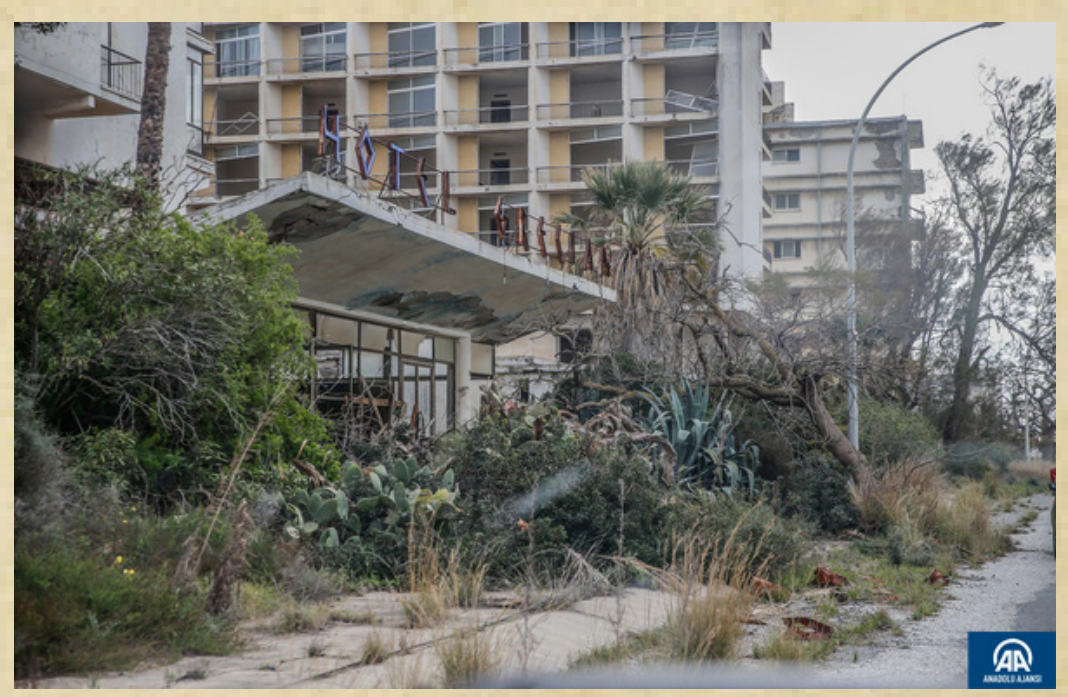

Görsel 6. Kapalı Maraş Bölgesi ${ }^{51}$

\section{Kapalı Maraş Bölgesinin Mekânsal Yalnızlığı Üzerine Kurgusal Denemeler}

Güncel sanat, bugünün insanının hemen her konudaki yaşam alanlarında kendisini var etmesi bakımından yeni bir sanat yapma edimini bizlere sunmaktadır. Bugünün sanatı salt güzellik arayışını değil, farklı pek çok soruna ait paradigmaları bilindik estetik normlar peşinde koşmayan bir anlayışta post yapısal bir biçimde karmaşık ve çarpık kurguları da referans alan bir yapıya evrilmiştir ${ }^{52} .20$. yüzyılın ikinci yarısından sonra gelişen Postmodern dönem ile birlikte sanat alanında başlayan paradigma değişimi dünyanın savaşlar sonrasında karşı karşıya kaldığı tüm sorunları sanat alanının içerisine dahil ederek genişlemiştir. Bu bağlamda yeniden şekil alan sanat üretimi gelişen sanayi ve endüstrinin de etkisiyle çeşitli eylem, hareket ve oluşumların yeni bir kavram metodolojisiyle çok farklı okumaların yapılmaya başladığı ve yapısal olarak sosyo - kültürel değişimleri de içine alan bir uzamda varlık alanı bulmuştur.

Güncel sanat karakteri itibari ile modern sanatın ilgi alanı dışında kalan her konu ve kavramı kucaklarken, sosyoloji, psikoloji, antropoloji, sosyal politikalar v.b. gibi diğer disiplin alanları içerisinde ele alınan konular ile bağlar kurmasını sağladı. Bu ilgi alanları o kadar çeşitliliğe kavuştu ki, yaşama ait her şey sanatın temel konusu olabildi. Aslında sanatın yaşamı kucaklaması onun normalleşmesiydi ${ }^{53}$

$51 \mathrm{Bu}$ fotoğrafın tüm hakları Anadolu Ajansı’na ait olup gerekli telif izinleri alınarak yayımlanmıştır. (Fotoğraf: Muhammet Fatih Oğraş) Kod: AA - 22617402 https://www.anadoluimages.com/p/kapalimaras-46-yilin-ardindan-kademeli-olarak-aciliyor/20572989, Erişim tarihi: 11.04.2021

52 Tansel Türkdoğan, Sanat Kültür Politika (Modernizm Sonrası Tartışmalar), Nobel Akademik Yayıncılık, Ankara 2019,s.49.

53 a.g.e, s.220. 
21. yüzyıldaki sanat anlayışı ve bunlara bağlı gelişen üretimler sanatçıyı kendisi ve çevresi ile yüzleştiren kültürel enstalasyonların entropisinde genel bir yapıya sahiptir ${ }^{54}$. Güncel sanat, içerisinde çok farklı katmanlara sahip olan okumaların yapıldığı bir bilinçle kendisine yeni bir alan açarken bu süreçte büyük gelişme gösteren teknolojinin öncül kabul edildiği yeni medya temelli aktif bir yaşam dizgesinde kendisini hissettirmektedir. Bu sebeple gelişen sayısal kodlu bilişsel dökümantasyonlar özellikle kent ve buna bağlı değişim gösteren yapısal kavramların ekoloji ve peyzaj bağlamında sosyolojik olarak psikotip betimlemeler üzerinde yeni bir standardı yakalamış ve sanat alanı içinde doğrudan özne konumuna geçmiştir.

Bireysel olarak yapılan çalışmalarda Kapalı Maraş bölgesinin geçmiş yaşantılar üzerinden temellendirilen bilince ait bellek okumaları üzerinde durulmuştur. Bu kapsamda bölgenin geçmişten kalan izlerinin adanın kentsel ve mimari motifleri üzerinden tıpkı süreç sanatında karşılaştığımız "1S1 ya da hava gibi doğal güçlerin etkisine bırakılan"55 bir süreçteki gibi yaşanmışlıkların yarım asıra yakın bir şekilde durduğu (47 yıl) "an” "lar multidisipliner ifadeler ve malzemeler üzerinden betimlenmeye çalışılmıştır. Bu kapsamda görsel 8'deki “Güncel Somut İkonalar” adlı çalışmada halihazırda bulunan ve 12 adet parçadan oluşan betimlemeler Kapalı Maraş bölgesinin belleğinde bulunan evler, terkedilmiş metruk binalar, tel örgüler, ağaçlar, kurumuş dallar, dikenler, yollar vb. simgesel ifadelere göndermede bulunarak alanın ekolojik olarak hinterlandı üzerinde 47 yıldır duraksamış olan hayatın görsel tanıkları gibi bir bilinçte düşünülmüştür. Buradaki bilinç kavramı bir bakıma tıpkı Ian Burn'un 1968 yılında yaptığı "Systematically Altereded Photograps - Sistematik Olarak Değiştirilmiş Fotoğraflar” adlı çalışmasında yapmış olduğu gibi orijinal görüntünün siyah beyaz noktalardan oluşan belli belirsiz imgelerindeki Avustralya yaşam tarzını simgeleyen düzenli ve geniş banliyöler ile çevresini ve görüntülere ait broşürlerdeki fotoğrafları sistematik olarak noktasal açıdan yok ederek fotoğraf üzerindeki tüm detayları gördüğümüz ve gördüklerimizden ne şekilde bahsettiğimizi sorgulatan çalışma serisindekine benzer olarak ${ }^{56}$ buradaki yaşanmışlıklara ait fotografik hafiza betimlemelerini birer anı şeklinde ortaya çıkarmaktır. Aslında Ian Burn'un yaptığı bir bakıma "dili dil üzerinde maddesel tasarı yapmaksızın incelemektir"57 (Bkz. Görsel 7), fakat görsel 8' de ise bu durum tam tersi bir şekilde ele alınmış ve sosyolojik tinsellikte bir betimleme ile sıradan görüntüler yerine tekinsizliği belli eden simgeler ayrıntılı biçiminde detaylandırılarak tam anlamıyla belirli bir netlikte oluşan görsellerin ifadeleri üzerinden doğa katmanları temellendirilerek sadece belli bir bölgeyi değil tüm mekânsal simgeleri detaylandıran sonradan doğal müdahaleler ile tekinsizlik simgelerini açıklayıcı bir unutulmazlıkta irdelenmiştir.

54 Mehtap Bingöl, Fatih Bingöl. Bilimsel ve Teknolojik Gelişmelerden Illham Alan Sanatlar, ASOS Journal: Akademik ve Sosyal Araştırmalar Dergisi, s. 106 -127 ,Y1l: 6, Sayı: 84, Aralık 2018 s. 123 https://asosjournal.com/?mod=tammetin\&makaleadi $=\&$ makaleurl=805852906_14453\%20Mehtap $\% 20$ B\%C4\%B0NG\%C3\%96L.pdf\&key=36212 Erişim tarihi: 04.05.2021.

55 Nancy Atakan, Sanatta Alternatif Arayışlar, Karakalem Kitabevi, İzmir 2015, s. 75.

56 https://www.mca.com.au/artists-works/works/199774a/, Erişim tarihi: 13.04.2021

57 Ferhat Özgür, "Yeni Medya Hazırlayıcısı Olarak Kavramsal Sanat” Bölümü: sf.200 -224. Ed. Deniz Yengin, Yeni Medya ve... Anahtar Kitaplar, İstanbul: 2012, s.222. 


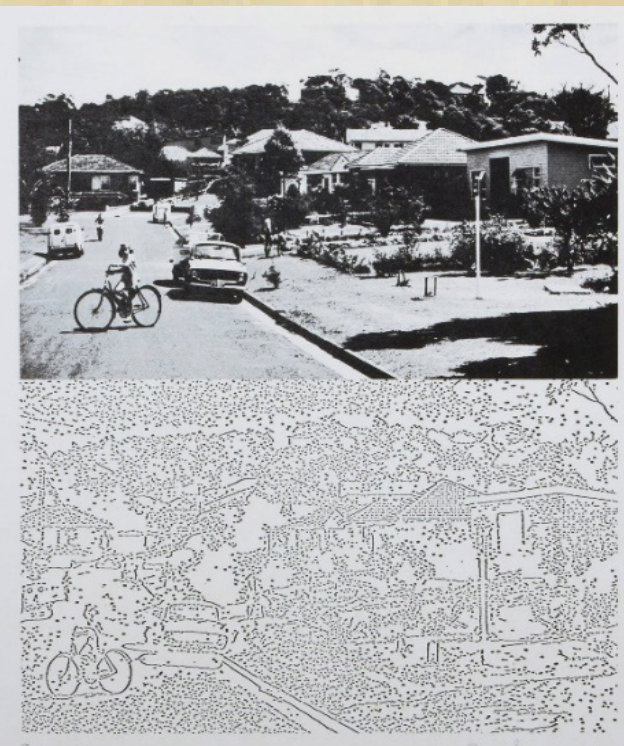

Görsel 7. Ian Burn, Sistematik Olarak Değiştirilmiş Fotoğraflar, "Sistematically Altered Photos", $1968 .^{58}$

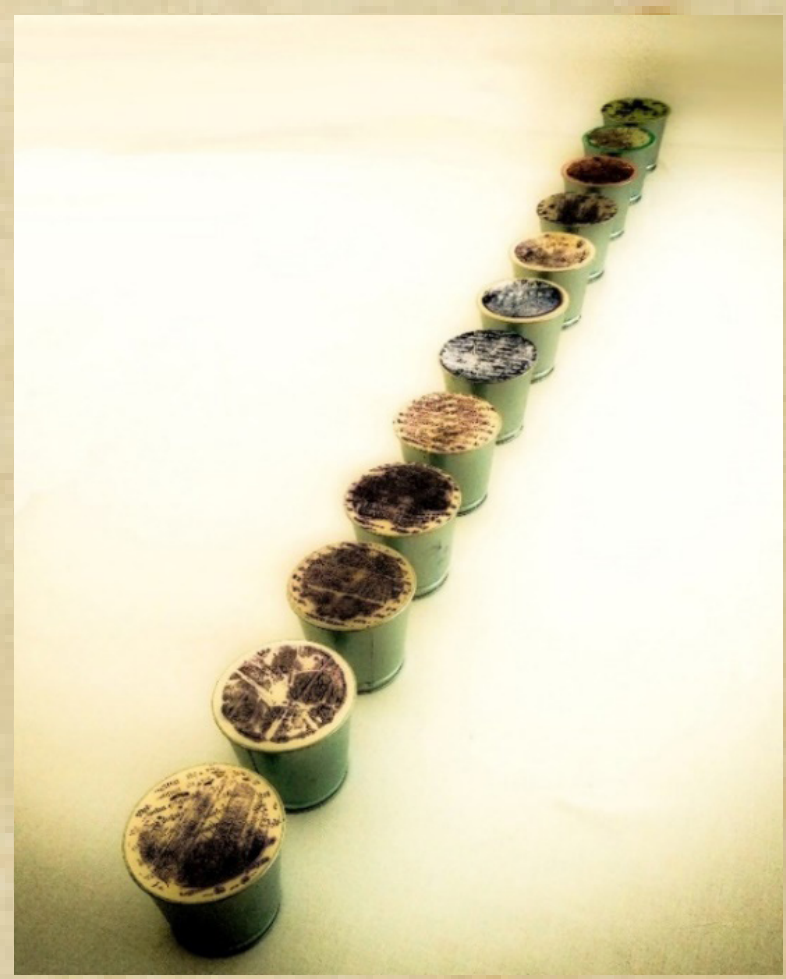

Görsel 8. Fırat Çağrı Kırmızıgül, Güncel Somut İkonalar Serisi, Karışık teknik, Değişken Ölçüler, $2021^{59}$

58 https://www.mca.com.au/artists-works/works/199774a/, Erişim tarihi: 13.04.2021

59 Fırat Çağrı Kırmızıgül Arşivi. 

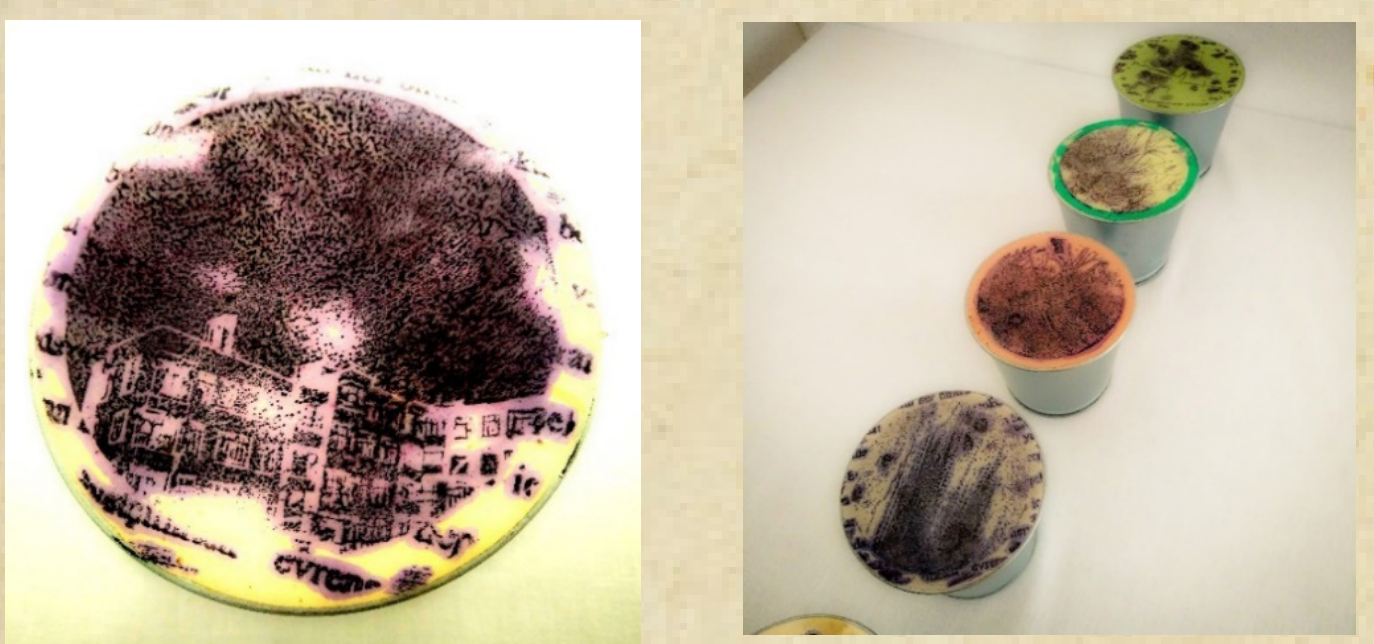

Görsel 9 - 10. Fırat Çağrı Kırmızı̈ül, Güncel Somut İkonalar Serisi (Detay) ${ }^{60}$.

"Düşlerimin ardına gizlenen beyazları...

Aramışım durmuşum yorulmuşum...

Ölmüşüm beyazlardan sorulmuşum... Aramışım durmuşum umutsuz yorulmuşum...

Ölmüşüm beyazlardan sorulmuşum..."

Feridun Düzağaç’ın 1996 yılında "Beni Rahatta Dinleyin" albümünde yer alan ve pek gün yüzüne çıkmamış olan "Beyaz" adlı şarkısında geçen bu sözler beyaz kavramına atfedilen melankolik bir ruh durumunun ortak bir renk simgesi olan beyaz ile betimlenmeye çalışılmıştır. Beyaz burada bir yandan belirsizliği ifade eden bir analitiği, bir yandan da hayatın merkezindeki bir bölümü de içine alan bir çizgide hayatın ta kendisi olarak acı bir şekilde bilinci simgeleyen dumana benzer bir olgudan oluşan örüntüdür. (Bkz. Görsel 11) Görsel 13'deki "Kesif" adlı çalışmada yer alan ve beyazdan griye çalan renk simgesi de tıpkı bu şarkıdaki gibi bir okuma metodolojisi ile Kapalı Maraş'ın geçmişten günümüze gelen değişmeyen envanterinde tüm mekanların belirsiz bir griliğe doğru dönüştüğünü bizlere anlatmaktadır. Bölgeye harita üzerinden bakıldığında dahi yörede yaşam izleri olmadığını ve haritanın civar bölgelere göre soluk (grimsi) bir renkte olduğu sonucuna varılmıştır. Burada yer alan grilik yaşantıların mekanlar üzerindeki izlerini bazı bölgelerde tamamen, bazı bölgelerde ise kısmen yok ettiğini bizlere göstermekte olup değişmeyen tek simgenin gökyüzü ve deniz mavisi olduğu mavi renk ile ifade edilmiştir (Görsel 12).

\footnotetext{
60 Fırat Çağrı Kırmızıgül Arşivi.

61 Albüm kartonetinden aktarılmıştır. Feridun Düzağaç, "Beni Rahatta Dinleyin" Albümü “Beyaz" adlı şark1. Söz: Feridun Düzağaç, 1996 - Prestij Müzik - Orjin Müzik. Bandrol No: KB 96.34.Ü.1049.024
} 

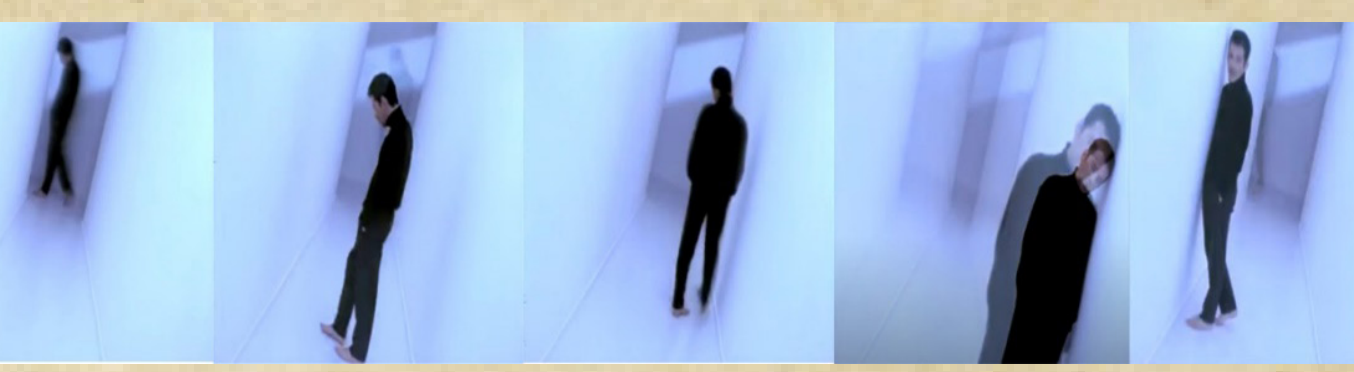

Görsel 11. Feridun Düzağaç, Beyaz, 4’04’, Yön. Mustafa Mayadağ, 1996 62.

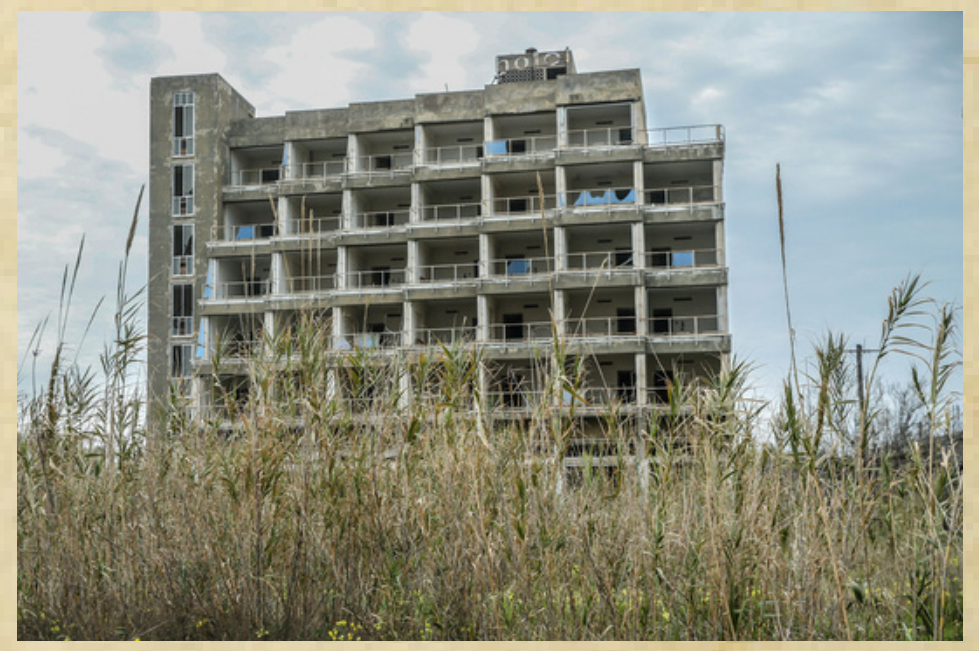

Görsel 12. Kapalı Maraş Bölgesi. ${ }^{63}$

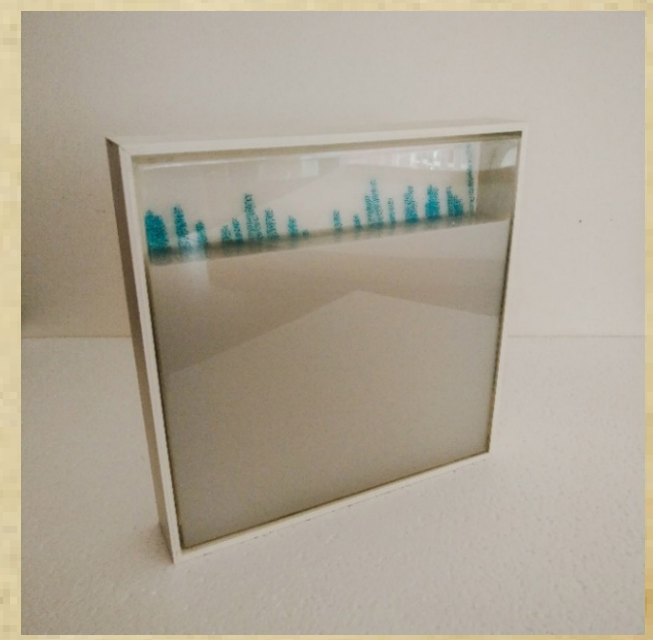

Görsel 13. Fırat Çağrı Kırmızıü̈l, Kesif, Pleksiglas, U.V baskı, ahşap, su. 25x25x4 cm, $2021^{64}$.

62 https://www.youtube.com/watch?v=jj4W4RgB11Q, Erişim tarihi:18.04.2021.

63 Bu fotoğrafın tüm hakları Anadolu Ajansı'na ait olup gerekli telif izinleri alınarak yayımlanmıştır. (Fotoğraf: Muhammet Fatih Oğraş) Kod: AA - 226174397 https://www.anadoluimages.com/p/kapalimaras-46-yilin-ardindan-kademeli-olarak-aciliyor/20572984, Erişim tarihi: 18.04.2021 
"Mekân deneyimininolağan dışı haliinsanı etkileyen, onu farklılaştıranbir etkisininolmasıdır... Mekânın düzenlenişi insanın ruhsal açıdan mekâna kendisini yansıtmasıyla gerçekleşmektedir" ${ }^{\circ 5}$. Görsel 14 ve 15 'de "Açık /Kapalı" adlı çalışmada yer alan imgesel betimlemede Kapalı Maraş bölgesine gönderme yapan bir kompozisyon şeklinde düzenlenmiş ve görselde yer alan yapı uzun zaman içinde kullanılmadığı için eskimiş ve yıkılmaya yüz tutmuştur. Burada bir yandan ölü doğa betimlenmeye çalışılırken bir yandan da onun eski ihtişamı neon renkleriyle bezenerek doğada temel olan renk dizeleri ile desteklenmiştir. Bu durum bir bakıma Strabonski'nin (2018) "Razı olunan bir ölümün araya girmesi üzerine insan ve tabiat arasındaki uyumu” gibi eski yapılarda kültür kalıntıları ve birikimlerine ait birer ruhsal bağlantılara sahip olarak doğa tarafından kuşatılmaktadır ${ }^{66}$. Strabonski'nin bu betimlemesi Kapalı Maraş'ın içinde bulunduğu durumuna benzer bir betimleme içerisindedir. Uzun y1llar ölüm sessizliğinde kalan bölge doğaya insan müdahalesi olmadan yapıları yıllar içinde kültürel belleği de yutarak bölgeyi belirsizliğe itme durumu gibi bir sonuca varmaktadır. Başka bir açıdan ise depresif bir durumda doğanın gücü kültürü yutan bir noktada ölümün kaçınılmaz sonu gibi bir yazgıya gönderme yaparken buradaki yazgı eskiye duyulan özlem ve doğanın huzuruna ait bilince dair varoluşta artık insanın olmadığı bir metafordur ${ }^{67}$. İmgelerin tüm yapılardaki bilince dair ifadesi eski yaşam alanlarını bir anlamda kutsayan da bir tavır içerisindedir. Bu bakımdan görselde yer alan çalışmadaki genel imgelem belleğin bütünsel ifade alanındaki yaşamsal süreçlerdeki bilinç psikozuna ait altyapılarda kendisini hissettirirken görselde yer alan fotoğraf " $o$ an” tipolojisine dair geçmiş mekanizmaları harekete geçiren bir anı olarak değerini korumaktadır. Burada görsel 14'deki fotoğraftaki "Açık” alan gündüz ve görsel 15' deki fotoğraf ise "Kapalı” şeklinde geceyi nitelendirilerek ifadelendirilmiştir. Çalışmada yer alan neon ise aynı zamanda belleğin her daim canlı olmasını simgeleyen bir eleman olarak düşünülmüştür (Görsel 14, 15).

65 Engin Ümer, Tekinsiz ve Temsil (Romantizmden Postmodernizme Bir İnceleme), Pales Yayınları, İstanbul 2018, s. 346

66 Strabonski'den akt. Engin Ümer, Tekinsiz ve Temsil (Romantizmden Postmodernizme Bir İnceleme), Pales Yayınları, İstanbul 2018, s. 347

67 a.g.e, s.347,348. 


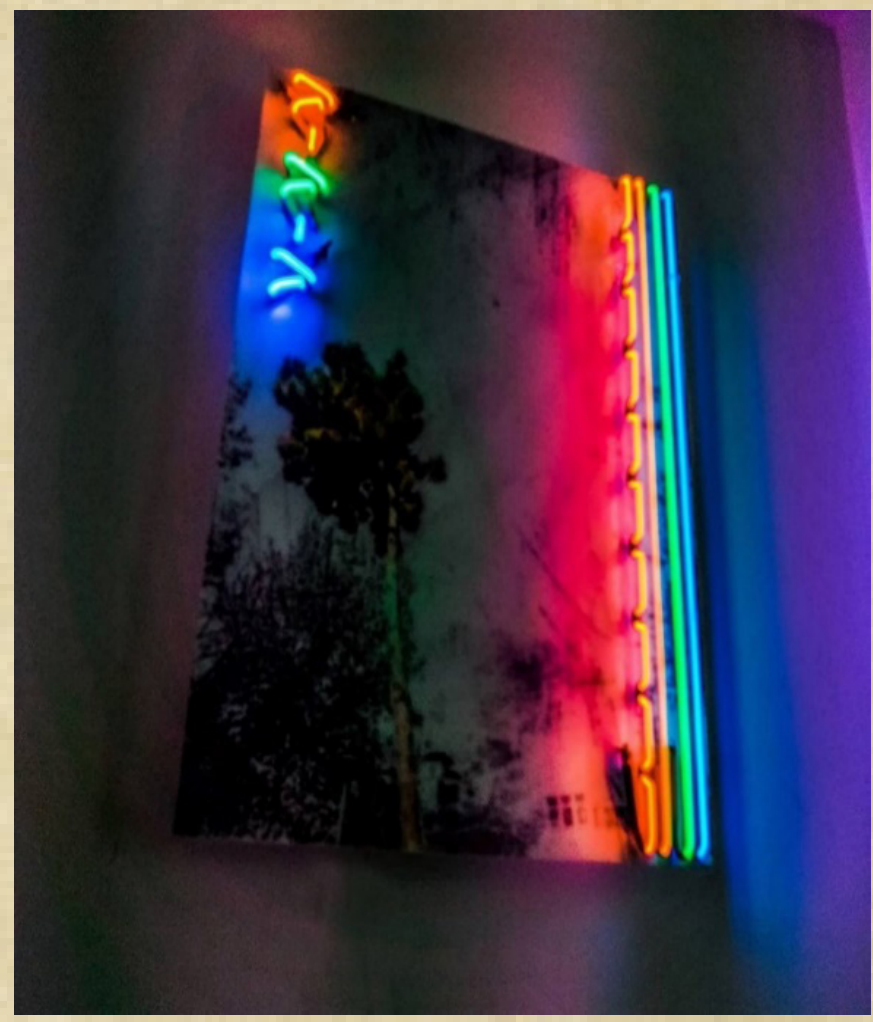

Görsel 14. Fırat Çağrı Kırmızıgül, Açık/Kapalı,(Açık) Neon. 60x100x20 cm, 202168

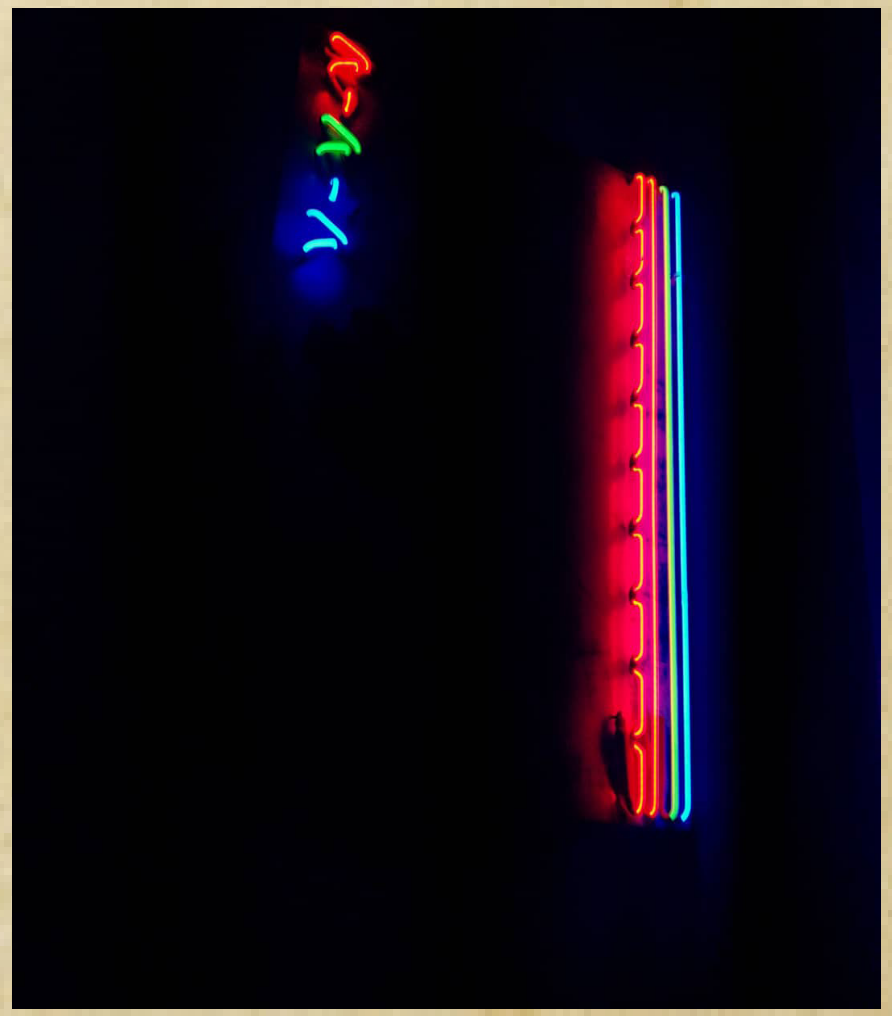

Görsel 15. Fırat Çağrı Kırmızıgül, Açık/Kapalı,(Kapalı) Neon. 60x100x20 cm, 2021 ${ }^{69}$ 
Görsel 17'de yer alan "Dönüşüm” isimli çalışmada ağaç betimlemesi fotoğraf, suluboya ve dijital düzenlemeye bağlı U.V tekniği ile birleştirilerek renklendirilmiştir. Bu kapsamda Kapalı Maraş'ın doğa kavramı tarifnamesi, üzerinde ayak basılmayan bir konuma geçiş yapmış ve doğa el değmeden kendi sıradanlığında yaşamaya devam etmiştir. Bu kapsamda mekanlar üzerinde de başlayan değişim, y1llara bağlı oluşan korozyonla birlikte bir anlamda da bölgenin betimlemesinde bizatihi bir simge halini almıştır. Görseldeki örnekte yer alan bir videodaki (Bkz. Görsel 16) detay üzerine projelendirilen bu çalışmada gördüğ̈̈müz yapısal durum zamanla baskın bir hal alarak yeni bir örüntü oluşturmuş ve bir anlamda renkler belli belirsiz olarak yeni bir düzlemde çerçevelendirilmiştir. Görsel 17 ve 18 ' deki çalışmada doğaya ait temel bir yapı taşı olan ağaç figürleri görsellerinin zamanla bölgenin yapısal alanlarını da kapladığı bizatihi bir örüntüye dönüşmüş ve farklı biçemlerde rengini yitiren bir belirsizliğe doğru dönüşüme uğratılarak çerçevelendirilmiştir.

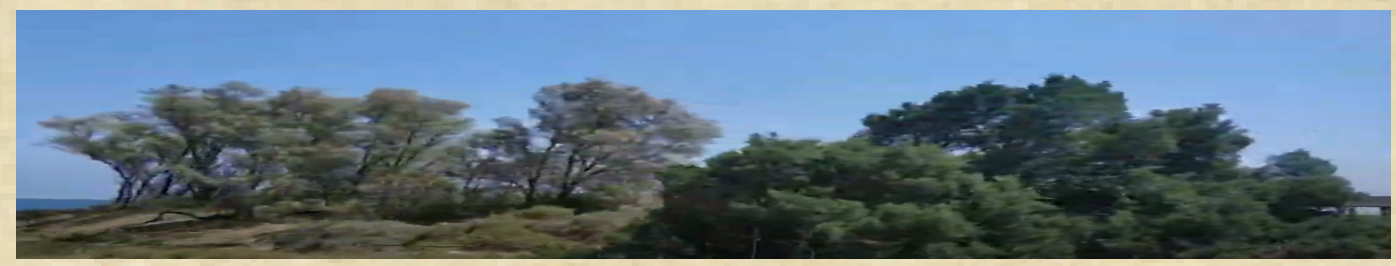

Görsel 16. Kapalı Maraş Vlog (Video Blog) görüntüsü70

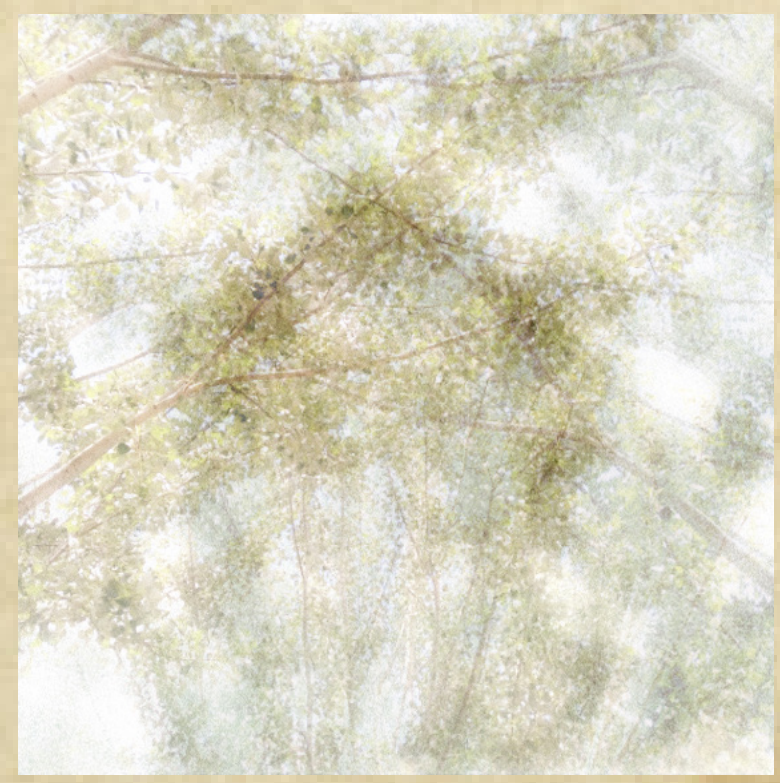

Görsel 17. Fırat Çağrı Kırmızıgül, Dönüşüm, Karışık Teknik

(Fotoğraf, suluboya, dijital renklendirme, U.V) $23 \times 23 \mathrm{~cm} .2021^{71}$.

70 Bu görüntü Youtube üzerinde yayın yapan Metam kanalından alınmış olup kanal sahibi tarafından çekilen Vlog videosuna aittir ve yayıncıdan gerekli izinler alınarak yayımlanmıştır: https://www.youtube.com/ watch?v=DpOOz1NXdFc, Erişim tarihi: 15.04.2021 


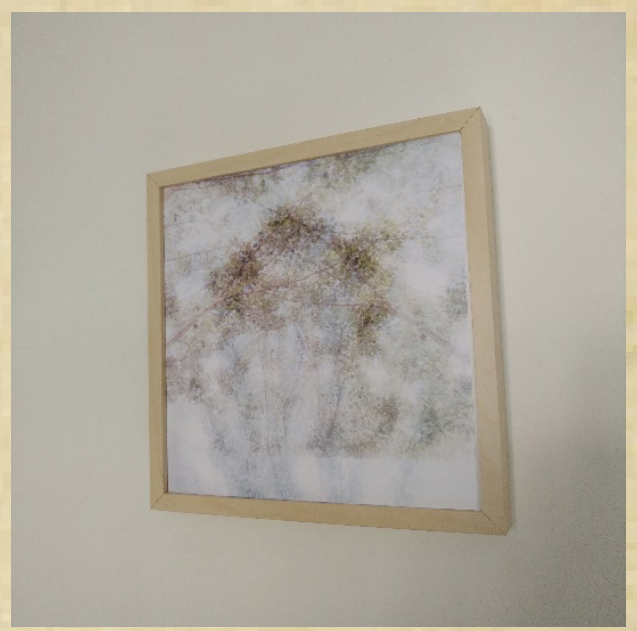

Görsel 18. Fırat Çağrı Kırmızıgül, Dönüşüm (Detay) ${ }^{72}$.

\section{Sonuç}

Bellek yaşanmışlıkların geçmiş ile gelecek arasında bir köprü oluşturan en önemli bilinç katmanlarının başında gelmektedir. Bu bakımdan bellek, bilince dair öz çıkarımların insan ile olan diyalektiği içerisinde psiko-sosyal bir dokümantasyon tipolojisinde bazen realiteye dayal1, bazen de metaforik imgelerden oluşan anılara dair yaşam parametrelerinden oluşur. İnsanoğlu yaşamında biriktirdiği pek çok hikâyeyi belleksel bir düzlemde ait olduğu kimlik ve mekanlar ile bütünleştirerek bu normlara göre hayatını devam ettirmekte ve çevresini oluşturduğu mekanlar ile sürekli olarak eklektik normlarla desteklemektedir. Mekanlar da insanın bu yaşamsal ögeleri içerisinde doğrudan bağlantılı olarak dinamik bir şekilde güncellenen yaşam arketipleri oluşturarak içerisinde daimî ve dinamik ögeler barındıran analojik ve tipolojik bir kavramdır. Kıbrıs adası da tam da bu noktada üzerinde pek çok medeniyetin yaşadığı ve bu medeniyetlerin yaşam dizgeleri ile anlam kazanarak çeşitli dinsel ve kimliksel paradigmalarla çok katmanlı melez bir yapıya sahip olması bakımından jeostratejik öneme sahip merkez konumunda bulunan bir adadır. Geçmişten günümüze pek çok sorunla yüz yüze kalmış olan bu ada üzerinde yıllardır çözülmeyi bekleyen sorunlarla karşı karşıya bir durumdadır. Çözülmeyi bekleyen bu sorunların simgesel bir hal aldığı en önemli mekanların başında ise Kapalı Maraş bölgesi gelmektedir. Maraş, 47 yıldır üzerinde ufak istisnalar haricinde aktif bir yaşam dizgesinin olmadığı topografik açıdan düz bir zemin üzerinde geçmiş üniter Kıbrıs kimliğini göstermesi bakımından adeta donmuş bir bölge durumdadır. Bölgenin uzun süredir insan müdahalesinden yoksun olan yapısı içerisinde tümel anlamdaki bellek uzamlarının olduğu ve doğal elemanların yapılar üzerindeki etkisini göstermesi bakımından adeta bir sergi salonunu andırmaktadır. Bu bakımdan Maraş ortak Kıbrıs aidiyetine sahip bilinç parametreleri ile oluşmuş bellek mekanizmalarını bölgenin görsel çıktıları ile oluşan halihazırdaki simgeleri çalışmanın en önemli çıktılarının başında gelen bir betimlemeye sahiptir. Kapalı Maraş bölgesi geçmiş yaşantıların kimlik bilinciyle melez düzlemdeki hasletlerle birleşerek eski ile yeni, geçmiş ile gelecek arasındaki farkları gösterirken düşündüren geniş ve çok çeşitli bir anı olarak her daim merak uyandıran bir anlama sahip kalacaktır. Yapılan çalışmalarda Kapalı Maraş bölgesinin 
mekânsal uzamında belleksel bilinç ile halihazırdaki yapısı üzerine bölge envanterinde bulunan pek çok yapı ve doğal elemanların disiplinlerarası tarzda sanatsal üretimleri oluşturulmuş ve bunlar simgesel bazda aktif yaşamın olmadığı alanlar üzerinden soyut ve kavramsal bir tarzda ele alınmıştır.

\section{Kaynaklar}

Armaoğlu, Fahir. 20. Yüzyıl Siyasi Tarihi (1914 -1995). Kronik Kitap, İstanbul: 2018.

Aslanapa, Oktay. Kıbrıs’ta Türk Eserleri. Kültür Bakanlığı Yayınları, İstanbul: 1975.

Atakan, Nancy. Sanatta Alternatif Arayışlar. Karakalem Kitabevi, İzmir: 2015.

Auge, Marc. Yok Yerler, (Çev. Turhan Ilgaz, Çev. Güncelleme. Ergun A. Akça, Arbil Ötkünç), Daimon Yayınları. İstanbul: 2016.

Bachelard, Gaston. Mekânın Poetikası, (Çev. Alp Tümertekin). İthaki Yayınları, İstanbul: 2020.

Balcı, Ali. Türkiye Dış Politikası. Alfa Kitap, İstanbul: 2017.

Bingöl, Mehtap, Bingöl Fatih. Bilimsel ve Teknolojik Gelişmelerden İlham Alan Sanatlar, ASOS Journal: Akademik ve Sosyal Araştırmalar Dergisi, s. 106 -127, Y11: 6, Sayı: 84, Aralık 2018 s. 123 *(Erişim Linki İnternet Kaynakçasındadır.)

Cevizci, Ahmet. Felsefe Sözlüğü. Say Yayınları, İstanbul: 2012.

Cevizci, Ahmet. Paradigma Felsefe Sözlüğü. Paradigma Yayıncılık, İstanbul: 2013.

Çabuklu, Yaşar. Uzam ve Kötülük. Everest Yayınları, İstanbul: 2006.

Çeçen, Anıl. Kıbrıs Çıkmazı. Astana Yayınları, Ankara: 2018.

Düzağaç Feridun. Beni Rahatta Dinleyin(Albüm), Orjin - Prestij Müzik Yapım. İstanbul:1996 Bandrol No: KB 96.34.Ü.1049.024

Jentsch, Ernest ve Freud, Sigmund. Ernest Jentsch: Tekinsizliğin Psikolojisi Üzerine, Freud Sigmunt: Tekinsizlik Üzerine (Çev. Hakan Şahin), Laputa Kitap, İstanbul: 2019.

Kalın, İbrahim. Barbar Modern Medeni, İnsan Yayınları. İstanbul: 2018.

Lefebvre, Henri. Mekânın Üretimi. (Türkçesi: Işık Ergüden), Sel Yayıncılık, İstanbul: 2019.

Morley, David \& Robins Kevin. Kimlik Mekanları, (Çev. Emrehan Zeybekoğlu). Ayrıntı Yayınları İstanbul: 2011.

Mütercimler, Erol. Satılık Ada Kıbrıs. Alfa Kitap, İstanbul: 2017.

Özgür, Ferhat. Bir "Yeni Medya Hazırlayıcısı Olarak Kavramsal Sanat” Bölümü: sf:200 -224. Ed. Deniz Yengin, Yeni Medya ve... Anahtar Kitaplar, İstanbul: 2012.

Soja, Edward W. Postmodern Coğrafyalar (Eleştirel Toplumsal Teoride Mekânın Yeniden İleri Sürülmesi) (Türkçesi: Yunus Çetin). Sel Yayıncılık: İstanbul: 2017.

Suner, Asuman. Hayalet Ev (Yeni Türk Sinemasında Aidiyet Kimlik ve Bellek). Metis Yayınları, İstanbul: 2015.

Türkdoğan, Tansel. Sanat Kültür Politika (Modernizm Sonrası Tartışmalar). Nobel Akademik 
Yayınc1l1k, Ankara: 2014.

Ümer, Engin. Tekinsiz ve Temsil (Romantizmden Postmodernizme Bir İnceleme). Pales Yayınları, İstanbul: 2018.

Yüksel, Yiğit Dilek. Kıbrıs Cumhuriyeti’nin Kuruluş Süreci ve Sorgulanan Varlı̆ğ (1878 1964). Berikan Yayınevi, Ankara: 2018.

\section{Internet Kaynakları}

https://www.aa.com.tr/tr/ulke-profilleri/kuzey-kibris-turk-cumhuriyeti-kktc/901503 ,Erişim tarihi: 08.04 .2021

*https://asosjournal.com/?mod=tammetin\&makaleadi=\&makaleurl=805852906_14453\%20 Mehtap\%20B\%C4\%B0NG\%C3\%96L.pdf\&key=36212 Erişim tarihi: 04.05.2021.

https://www.ayazrentacar.com/kibris-tatil-rehberi/kibrista-kilise-katedral-manastir. Erişim tarihi: 15.04 .2021

http://www.gazetevatan.com/maras-neden-kapatildi-kapali-maras-hikayesi-nedir-46-yildirkim-1346792-gundem/ Erişim tarihi: 11.04.2021

https://www.mca.com.au/artists-works/works/199774a/, Erişim tarihi: 13.04.2021

http://www.tamk.gov.ct.tr/index.html Erişim tarihi: 11.04.2021

http://users.metu.edu.tr/birten/tarih.html, Erişim tarihi: 15.04.2021

\section{Görsel Kaynaklar}

Görsel 1. https://turkinfo.hu/wp-content/uploads/2019/12/kktc-haritasi.jpg Erişim tarihi: 10.04.2021

Görsel 2. http://www.evkaf.org/site/sayfa.aspx?pkey=1195, Erişim tarihi: 17.04.2021

Görsel 3. https://earth.google.com/web/search/kapal\%c4\%b1+mara\%c5\%9f/@35.103789 61,33.95839446,12.7801814a,9508.92869027d,35y,-109.92871921h,44.99999747t,0r/data=Cnk aTxJJCiUweDE0ZGZjODZmMzU2ZWJjMTU6MHg3NzcwMTRjNWYxOTZiZjVjGfPHtDaNj UFAIeoQ7oRN-kBAKg5rYXBhbMSxIG1hemHFnxgCIAEiJgokCYutPSGhnEFAEWjA9ZJleU FAGYtgAV_WHEFAIWbnrGEd6kBA Erişim tarihi: 11.04.2021

Görsel 4. Kapalı Maraş Bölgesi, KKTC. (Bu fotoğrafın tüm hakları Anadolu Ajansı'na ait olup gerekli telif izinleri alınarak yayımlanmıştır). (Fotoğraf: Kültür ve Turizm Bakanlığı) Kod: AA - $19166357 \mathrm{https} / / / \mathrm{www}$.anadoluimages.com/p/ersoy-kktcde-kapali-maras-bolgesini-inceledi/16816167 Erişim tarihi: 11.04.2021

Görsel 5. Kapalı Maraş Bölgesi, KKTC. (Bu fotoğrafın tüm hakları Anadolu Ajansı'na ait olup gerekli telif izinleri alınarak yayımlanmıştır). (Fotoğraf: Muhammet Fatih Oğraş) Kod: AA - $22617396 \mathrm{https} / /$ www.anadoluimages.com/p/kapali-maras-46-yilin-ardindan-kademeli-olarakaciliyor/20572983, Erişim tarihi: 11.04.2021

Görsel 6. Kapalı Maraş Bölgesi, KKTC. (Bu fotoğrafın tüm hakları Anadolu Ajansı'na ait olup gerekli telif izinleri alınarak yayımlanmıştır). (Fotoğraf: Muhammet Fatih Oğraş) Kod: AA - $22617402 \mathrm{https} / /$ www.anadoluimages.com/p/kapali-maras-46-yilin-ardindan-kademeli-olarakaciliyor/20572989, Erişim tarihi: 11.04.2021 
Görsel 7. https://www.mca.com.au/artists-works/works/199774a/ Erişim tarihi: 13.04.2021

Görsel 8,9,10. Fırat Çağrı Kırmızıül Arşivi

Görsel 11. https://www.youtube.com/watch?v=jj4W4RgB11Q, Erişim tarihi:18.04.2021

Görsel 12. Kapalı Maraş Bölgesi, KKTC. (Bu fotoğrafın tüm hakları Anadolu Ajansı'na ait olup gerekli telif izinleri alınarak yayımlanmıştır). (Fotoğraf: Muhammet Fatih Oğraş) Kod: AA -

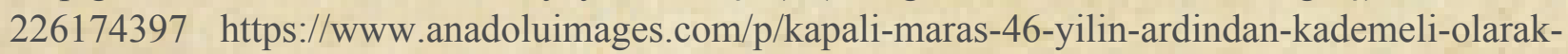
aciliyor/20572984,Erişim tarihi: 18.04.2021

Görsel 13, 14, 15. Fırat Çağrı Kırmızıgül Arşivi

Görsel 16. https://www.youtube.com/watch?v=DpOOz1NXdFc, Erişim tarihi: 15.04.2021

Görsel 17,18. Fırat Çağrı Kırmızıgül Arşivi 